OPEN ACCESS

Edited by:

Damien Keating,

Flinders University, Australia

Reviewed by:

Rudy M. Ortiz,

University of California, Merced,

United States

Carol Huang,

University of Calgary, Canada

*Correspondence:

Philip Newsholme

philip.newsholme@curtin.edu.au

Rodrigo Carlessi

rodrigo.carlessi@curtin.edu.au

Specialty section:

This article was submitted to

Cellular Endocrinology,

a section of the journal

Frontiers in Endocrinology

Received: 22 August 2018

Accepted: 29 October 2018

Published: 23 November 2018

Citation:

Rowlands J, Heng J, Newsholme P and Carlessi $R$ (2018) Pleiotropic Effects of GLP-1 and Analogs on Cell Signaling, Metabolism, and Function.

Front. Endocrinol. 9:672. doi: 10.3389/fendo.2018.00672

\section{Pleiotropic Effects of GLP-1 and Analogs on Cell Signaling, Metabolism, and Function}

\author{
Jordan Rowlands, Julian Heng, Philip Newsholme* and Rodrigo Carlessi* \\ School of Pharmacy and Biomedical Sciences, Curtin Health Innovation Research Institute, Perth, WA, Australia
}

The incretin hormone Glucagon-Like Peptide-1 (GLP-1) is best known for its "incretin effect" in restoring glucose homeostasis in diabetics, however, it is now apparent that it has a broader range of physiological effects in the body. Both in vitro and in vivo studies have demonstrated that GLP-1 mimetics alleviate endoplasmic reticulum stress, regulate autophagy, promote metabolic reprogramming, stimulate anti-inflammatory signaling, alter gene expression, and influence neuroprotective pathways. A substantial body of evidence has accumulated with respect to how GLP-1 and its analogs act to restore and maintain normal cellular functions. These findings have prompted several clinical trials which have reported GLP-1 analogs improve cardiac function, restore lung function and reduce mortality in patients with obstructive lung disease, influence blood pressure and lipid storage, and even prevent synaptic loss and neurodegeneration. Mechanistically, GLP-1 elicits its effects via acute elevation in CAMP levels, and subsequent protein kinase(s) activation, pathways well-defined in pancreatic $\beta$-cells which stimulate insulin secretion in conjunction with elevated $\mathrm{Ca}^{2+}$ and ATP. More recently, new studies have shed light on additional downstream pathways stimulated by chronic GLP-1 exposure, findings which have direct relevance to our understanding of the potential therapeutic effects of longer lasting analogs recently developed for clinical use. In this review, we provide a comprehensive description of the diverse roles for GLP-1 across multiple tissues, describe downstream pathways stimulated by acute and chronic exposure, and discuss novel pleiotropic applications of GLP-1 mimetics in the treatment of human disease.

Keywords: GLP-1, signaling, diabetes, metabolism, cell function and integrity

\section{INTRODUCTION}

While its gene was first cloned in 1983, and protein product approved as a therapeutic agent for Type 2 diabetes mellitus (T2D) in 2005, the mammalian glucagon-like peptide-1 (GLP-1), its modes of action, and various analogs, have been and are still widely studied. As it is a highly attractive T2D therapy, the major known functions of the incretin peptide GLP-1 and analogs are based on studies delineating its role in the endocrine pancreas. GLP-1 acts through binding to its receptor (GLP-1R), triggering a downstream signaling cascade able to induce a potent stimulation of glucose stimulated insulin secretion (GSIS) in $\beta$-cells, as well as inhibition of $\alpha$-cell glucagon release. GLP-1 analogs, such as Liraglutide and Exendin-4, unlike endogenously produced GLP-1, are not rapidly degraded by Dipeptidyl peptidase-4 (DPP-4) and, therefore, can induce sustained therapeutic actions, that 
otherwise would not be possible due to the exceedingly short half-life of endogenous GLP-1 in circulation. GLP-1R is a B class G-protein-coupled receptor abundantly expressed in the pancreas and central nervous system, but also detected in lower levels in the gut, kidneys, lungs, liver, heart, muscle, peripheral nervous system, and other tissues (1). Upon binding to the receptor, GLP-1 and its analogs also initiate a variety of additional anti-diabetic effects, including, but not limited to, reduction in gastric emptying, increase in satiety and inhibition of food motivated behavior, replenishment of insulin stores, as well as cytoprotective and anti-inflammatory actions on $\beta$-cells (29). To initiate these beneficial effects, however, GLP-1 must first be secreted from either the enteroendrocine L-cells, the preproglucagon (PPG) neurons located in the nucleus of the solitary tract of the brain stem, or, as reported recently, the $\alpha$-cells in the pancreas (10-14). Upon ligand binding, GLP-1R initiates a cascade that involves activation of membrane bound Adenyl Cyclase (AC) and consequent production of cyclic adenosine monophosphate (cAMP). Downstream of cAMP formation, several signal transduction pathways can be initiated, which generally require activation of either one or both of the cellular cAMP effectors, Protein kinase A (PKA) and exchange protein directly activated by cAMP (EPAC) [reviewed in $(15,16)]$.

GLP-1R mediated effects arise as a consequence of the immediate signaling cascade, which can impact insulin secretion and calcium flux in a rapid post translational modifications based manner $(4,17)$, and/or, the late stage or chronic effects, which can operate through modulation of gene expression and cellular metabolism (18-21). To date, the vast majority of studies have tended to focus on the acute impact of GLP-1R activation. More recently, research has begun elucidating the consequences of chronic GLP-1R stimulation (19, 22-25). Longlasting GLP-1 analog treatments are now in regular clinical use, and their impact, safety and efficacy are well-established and extensively reviewed (25-31). However, a succinctly summarized and current understanding of the signaling mechanisms and metabolic impact of chronic GLP-1R agonist activity on $\beta$-cells, and more broadly, across other tissues is both essential and lacking. To this end, our review outlines the current knowledge in regards to GLP-1R activation, subsequent signaling events, and discuss recent findings, firstly with respect to the wellcharacterized pancreatic $\beta$-cell, followed by effects on other cell and tissue types.

\section{ACUTE EFFECTS OF GLP-1 IN $\beta$-CELLS}

Glucose enters the pancreatic $\beta$-cells via the transporter, Glucose transporter 2 (GLUT2), moving down a concentration gradient from the capillaries. In the cytosol glucose is phosphorylated by the enzymes glucokinase/hexokinase (glucokinase is the predominant isoform in the $\beta$-cell), after which it enters the glycolytic pathway. Rapid catabolism of glucose via glycolysis and mitochondrial TCA cycle activity generates ATP $(32,33)$. The subsequent increase in $\mathrm{ATP} / \mathrm{ADP}$ ratio leads to a closure of ATPsensitive $\mathrm{K}^{+}$channels, intracellular accumulation of $\mathrm{K}^{+}$ions and subsequent membrane depolarization, causing an influx of $\mathrm{Ca}^{2+}$ via voltage dependent $\mathrm{Ca}^{2+}$ channels (VDCC). This $\mathrm{Ca}^{2+}$ influx, along with elevated ATP, results in exocytosis of the plasma membrane docked immediate release pool (IRP) of insulin granules, a sub-pool of the readily releasable pool (RRP) which contains $\sim 1-5 \%$ of available insulin granules $(16,34)$. This is the main driver behind $\beta$-cell $1^{\text {st }}$ phase stimulus-secretion coupling, since it is the products of glucose catabolism that ultimately drive insulin exocytosis. This release is rapid, and is known to peak at around $10 \mathrm{~min}$ from the initial glucose challenge, whilst the second phase of insulin release, which is sustained, consists in the release of granules from the larger Reserve pool (RP), containing 95-99\% of insulin granules, and lasts until glucose stimulation ends (30-60 min under normal physiologic conditions) $(16,35)$. Before the trafficking and release of the RP granules occur, granule competency must be achieved, and this is believed to occur through granule acidification resultant from an increase of $\mathrm{H}^{+}$and $\mathrm{Cl}^{-}$ions and processing of pro-insulin into mature, releasable, insulin (36).

In pancreatic $\beta$-cells, GLP-1R stimulated pathways act promptly (seconds to minutes) to potentiate glucose-dependent insulin release. This is achieved by a rapid increase in cAMP, which is accompanied by direct activation of PKA and EPAC. These two effectors of cAMP signaling modify several targets within the secretory machinery, with the net effect to synergistically enhance the amount of insulin secreted in response to glucose stimulation $(15,16)$. Indeed, several independent mechanisms are also reported to act in concert in order to result in enhanced insulin secretion, as discussed below (Figure 1).

Activation of PKA by cAMP results in release of its two catalytic subunits from the two anchoring regulatory subunits from specific cellular locations and anchoring proteins. Activated PKA can directly phosphorylate the sulphonylurea receptor (SUR1 as well as a regulatory subunit of $\mathrm{K}^{+} \mathrm{ATP}$ channels, thereby reducing SUR1 affinity to ADP, and increasing activity of $\mathrm{K}_{\mathrm{ir} 6.2}$, respectively (37). This, in turn, leads to channel closure and increased accumulation of intracellular $\mathrm{K}^{+}$ions (9), influx of $\mathrm{Ca}^{2+}$ and promotion of insulin secretion in response to GLP-1 stimulation.

Another cAMP effector, EPAC, is implicated in $\mathrm{K}^{+} \mathrm{ATP}$ channel regulation. Kang, et al. demonstrated that activation of EPAC reduces the concentration of ATP required to achieve closure of $\mathrm{K}^{+}$ATP channels (38). This indicates that in the presence of active EPAC, lower concentrations of ATP promote membrane depolarization and subsequent insulin granule exocytosis. Indeed, acute exposure to EPAC can stimulate insulin granule exocytosis and maturation, through sensitization of the ryanodine receptors and activation of the calcium sensing complex $(16,39,40)$. EPAC aids insulin priming and release via facilitating formation of a Rim2/Rab3a complex via Rim2/EPAC interaction (3, 41-43). Rim2/Rab3a complex interacts with the $\mathrm{Ca}^{2+}$ sensor Piccolo-CAZ (cytoskeletal matrix protein that associates with the active zone) to facilitate vesicle exocytosis at the cytoplasmic surface of the insulin granule (3, 41, 42, 44). However, enhanced vesicle mobilization, priming, and subsequent exocytosis is not only regulated by the EPAC pathway, but also directly by PKA. PKA can facilitate insulin secretion 


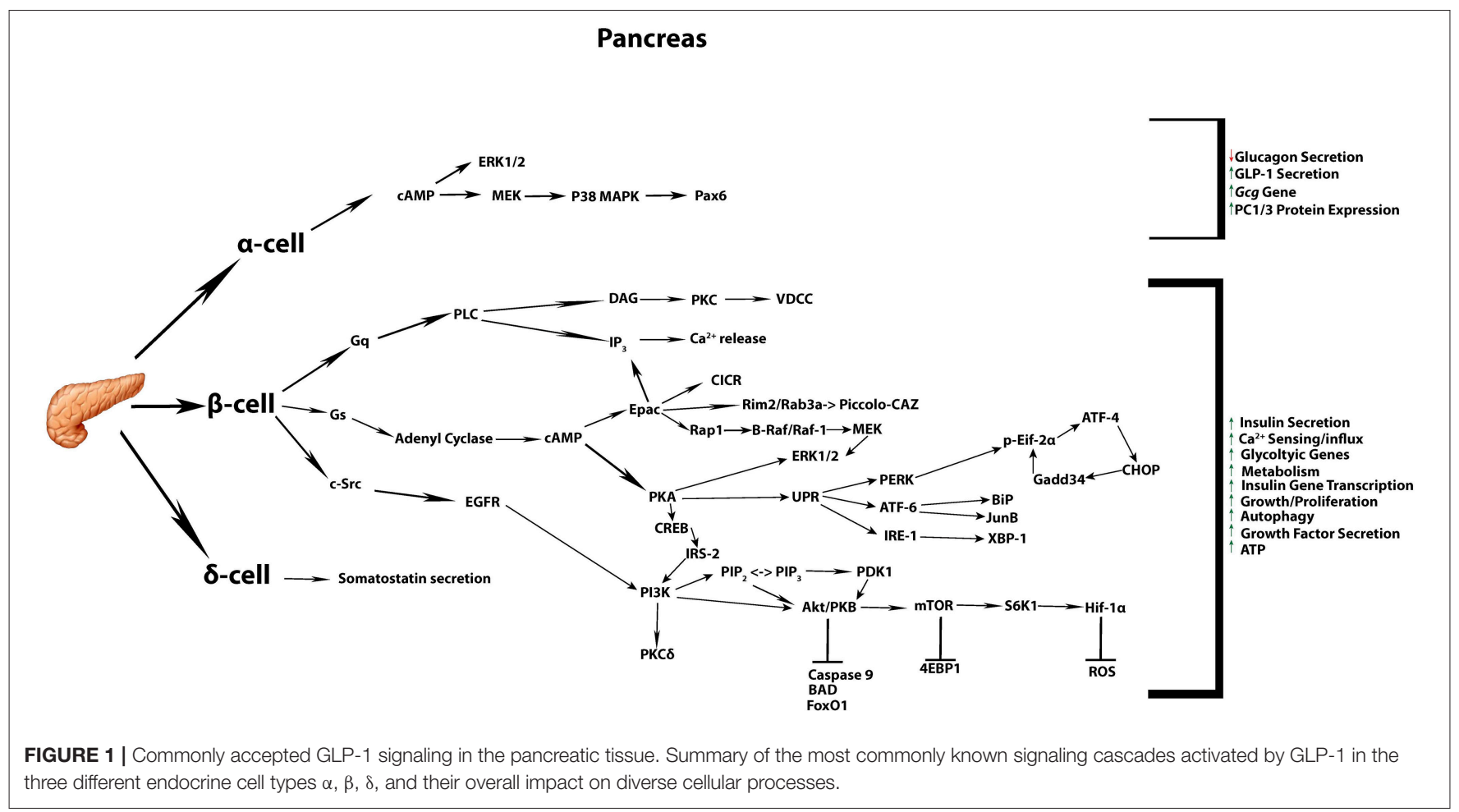

through regulation of $\mathrm{Ca}^{2+}$ secretion, whereby PKA sensitizes the inositol triphosphate receptor leading to release of $\mathrm{Ca}^{2+}$ from intracellular stores $(16,45-47)$. PKA has also been reported to accelerate the competency and mobilization of vesicles from the reserve pool of insulin to the readily releasable pool and, thus, enhance $\mathrm{Ca}^{2+}$-dependent exocytosis in mouse pancreatic islets $(16,34,48,49)$. Indeed, a recent report described that PKA activity is required for glutamate uptake into the insulin granules, with glutamate uptake potentiating insulin release (50). Cytoplasmic glutamate can be derived via the malateaspartate shuttle following pyruvate mitochondrial metabolism. Since glucose metabolism is absolutely required for GLP-1induced stimulation of insulin secretion, the latter mechanism represents a clear link between glucose metabolism and GLP-1 action via PKA to amplify insulin secretion.

\section{CHRONIC EFFECTS OF GLP-1 IN $\beta$-CELLS}

It is perhaps unsurprising that GLP-1 therapeutics show greater efficacy compared with traditional diabetic medicines, due to their potential to address not only acute stimulation of insulin secretion in response to a rise in blood glucose, but also slow the progressive loss of $\beta$-cell function and tissue mass in T2D. The beneficial effects of GLP-1 are resultant from cAMP mediated signaling, and ultimately activation of pro-survival cAMP responsive element binding (CREB) signaling, as well as the non-receptor tyrosine kinase/c-Src, transactivation of EGFR $(5,40,51)$. CREB and EGFR pathways induce pro-survival and anti-apoptotic responses (52-57), including increased expression of anti-apoptotic genes (58), attenuation of ER stress (59), prevention of oxidative stress and fatty acid mediated toxicity
(60). cAMP binds to PKA regulatory subunits, releasing and activating PKA catalytic subunits that cause phosphorylation of $\mathrm{CREB}$ at $\mathrm{Ser}^{133}$, promoting its activation and subsequent binding to genes containing palindromic CRE repeat sequences. Activated CREB regulates the expression of several genes essential for normal $\beta$-cell function, including the insulin gene (61). Additionally, EPAC can also exert late stage effects through the Rap1 protein, a small GTPase that regulates B-Raf/Raf1 activation via a combination of residue phosphorylation $\left(\mathrm{Ser}^{338}\right)$ and dephosphorylation $\left(\mathrm{Ser}^{259}\right)$, which enables Raf to phosphorylate the mitogen-activated protein kinase (MEK). MEK, in turn, phosphorylates the threonine and tyrosine residues of the extracellular-signal regulated kinases (ERK) 1 and 2, which regulate gene expression, growth and differentiation (62, 63). In addition to protection against apoptosis, it has been proposed that GLP-1 induces $\beta$-cell proliferation in rodent cell lines and in isolated rodent islet cells (54, 55, 64). However, these findings have varying results in human cells, with a recent study identifying an age-dependent Exendin4 induced signaling mechanism regulating $\beta$-cell proliferation (65). This study revealed that unlike adult human islets, juvenile human islets transplanted into an immunocompromised strain of mice suitable for xenograft studies retained their insulin secreting properties, and possessed a mitogenic response to a pharmacologically relevant infusion of Exendin-4. The mitogenic effect of chronic exposure of Exendin- 4 in these transplanted mice was observed to arise from stimulation of the calcineurin/nuclear factor of activated $\mathrm{T}$ cells (NFAT) signaling pathway, leading to a variety of target genes essential for proliferation (65). Furthermore, this ability to enhance $\beta$-cell mass has been recently challenged in a study conducted in 
normoglycaemic mice where $\beta$-cell mass was decreased following 6 weeks of treatment with Liraglutide $(66,67)$. Therefore, GLP1 analogs can have contrasting effects on $\beta$-cell proliferation depending on physiological context.

A physiological consequence of T2DM, due to peripheral insulin resistance, is high demand for enhanced insulin protein synthesis in the $\beta$-cell. It has been observed that sustained exposure to high insulin synthesis requirement results in ER stress due to protein overload and misfolding (68-72). The unfolded protein response (UPR) is the biochemical program initiated within the cell to counteract the accumulation of unfolded proteins in the ER lumen resulting in destabilization of ER homeostasis (73). The UPR initiates signaling cascades involving the luminal domains of three major ER resident proteins; Inositol requiring enzyme 1 (IRE1), protein kinase $\mathrm{R}$ (PKR)-like endoplasmic reticulum kinase (PERK), and activating transcription factor 6 (ATF6) $(71,74)$. The pathways so activated via signaling hubs attempt to re-establish ER homeostasis through transcriptional activation of genes involved in protein folding and protein degradation, as well as temporary attenuation of mRNA translation (75-77). This is achieved through downstream signaling events as, phosphorylation of eukaryotic translation initiation factor 2 alpha (eIF2 $\alpha$ ), resulting in global protein synthesis blockade, and alternative splicing of X-box binding protein 1 (XBP-1), a transcription factor involved in misfolded protein retrotranslocation and degradation (7880). Failure to alleviate ER stress, and consequent prolonged UPR activation, leads to apoptotic cell death primarily through upregulation of the pro-apoptotic transcriptional factor C/EBP homologous protein (CHOP) $(71,81,82)$. Several physiological and environmental insults associated with T2DM have been shown to induce ER stress in $\beta$-cells, these include hyperglycemia, dyslipidemia, inflammation and oxidative stress (83).

GLP-1 has been reported to alleviate glucotoxicity, lipotoxicity, excess nitric oxide (NO), $\mathrm{Ca}^{2+}$ depletion, oxidative stress, and cytokine-induced ER stress in both primary $\beta$-cells and cell lines through several downstream signaling mechanisms (59, 74, 84-86). For example, Yusta, B et al., demonstrated that GLP-1R signaling facilitates the shift from translational repression to translational recovery phase in a PKA-dependent manner (74). The recovery phase is concomitant with enhanced activation of ATF-4, CHOP and over-stimulation of Gadd34 gene signaling cascade, which leads to eIF2 $\alpha$ dephosphorylation. Furthermore, GLP-1 treatment leads to upregulation of spliced XBP-1 (sXBP-1), which is involved, along with ATF6, in enhancing ER function through activation of genes encoding molecular chaperones and ER-associated protein degradation $(60-70,74)$. In addition, GLP-1 protection from lipotoxic stress has been demonstrated to occur downstream from induction of the ER chaperone Binding immunoglobulin Protein (BiP) and anti-apoptotic protein JunB (86). Animal studies have recapitulated these findings, whereby diabetic mice treated with GLP-1 analogs displayed a significant reduction in biochemical markers of ER stress, increased expression of antioxidant genes and improved metabolic parameters $(60,74)$.

Most recently, GLP-1 has also been implicated in the regulation of autophagy in $\beta$-cells $(87,88)$. Autophagy, a mechanism that can promote cell survival during nutrient depletion, may also occur under basal and excessive nutrient conditions. This cellular process is characterized by the formation of autophagosomes, which can capture cytosolic components and fuse with lysosomes to promote the recycling and/or degradation of its contents. The process can be separated into four stages, initiation, nucleation, elongation, and fusion/degradation [reviewed in (89)]. Initiation is controlled by the mammalian Target of rapamycin (mTOR)/ AMP-activated protein kinase (AMPK)/ Uncoordinated (Unc)-51-like kinase 1 or 2 (ULK$1 / 2$ ) axis, a crucial regulatory step leading to the activation of class III phosphatidylinositol 3-kinase complex, formation of the phagophore (a double membrane vesicle that encloses and isolates the cytoplasmic components during autophagy), and ultimately, recruitment of key proteins involved in the nucleation phase (90). Once the phagophore is formed, the elongation phase is undertaken where the phagophore captures the desired cargo for degradation. This is regulated by two ubiquitin-like reactions that act in concert to mediate the localization of key proteins to the developing autophagosome, and expansion of its membrane (91-93). Finally the autophagosome fuses with lysosomes, after which lysosomal enzymes initiate content degradation and nutrient and metabolite recycling (92). Autophagy provides essential components for energy production and biosynthesis during nutrient depletion. However, it also acts in a similar fashion by recycling of damaged organelles, unwanted proteins and foreign matter when adequate nutrients are available (88). In an environment with excessive nutrients, however, autophagy acts to remove unfolded proteins and toxic aggregates, thus facilitating ER homeostasis. GLP-1 can facilitate autophagy under chronic exposure to excess nutrients, whereby it prevents autophagosomal-lysosomal fusion impairment (87, 88). Similarly, Exendin- 4 was reported to enhance lysosomal function, consequently leading to improved autophagosome clearance in a rat model of tacrolimus-induced diabetes whereby autophagosome accumulation causes islet injury (94). In the latter study, in vivo Exendin-4 treatment decreased tacrolimusinduced hyperglycemia, oxidative stress, and apoptosis. In parallel, it was demonstrated that $\beta$-cells from treated animals presented with reduced autophagosome numbers and decreased autophagy related protein expression. Thus, GLP-1R signaling could be interpreted as inhibiting autophagy, however, it most likely depicts its positive effects on autophagosomal-lysosomal fusion and, therefore, as a positive mediator of autophagic flux. It should be noted, however, that GLP-1 induced changes can vary depending on the underling mechanism of stress. For example, while usually promoting autophagy, treatment with GLP-1 analogs in a high fructose fed rat model resulted in apparent inhibition of $\beta$-cell autophagy, and increase in $\beta$-cell mass and function (95). The underlying mechanisms and downstream molecular mediators through which GLP-1 influences autophagy remain to be better characterized.

Recently, several studies have significantly improved our understanding of the regulation of $\beta$-cell energy metabolism by chronic GLP-1R activation. Notably, acute vs. chronic effects of receptor activation and downstream cAMP signaling leads to two distinct waves of gene expression regulation in primary 
islet cells. The initial wave of gene expression occurs as rapidly as $2 \mathrm{~h}$ after cAMP elevation upon acute receptor activation, and is mediated by CREB. Sixteen hours from the initial stimulation, a second wave of gene expression regulation takes place, and is orchestrated by Hypoxia-inducible factor 1 (HIF1), a transcriptional factor that targets genes involved with glucose uptake and glycolysis (21). Van de Velde et al. reported that chronic GLP-1R activation led to metabolic reprogramming marked by increased ATP production and upregulation of glycolytic enzymes, occurring as a result of late activation of subunit alpha of HIF-1 (HIF-1 $\alpha$ ) downstream of mTOR. This finding is consistent with a recent study demonstrating that depletion of HIF- $1 \alpha$ or inhibition of mTOR impaired the effects of GLP-1R signaling on glycolysis (18). Whilst it is known that the Phosphoinositide 3-kinase (PI3K) /AKT (Protein kinase B) /mTOR axis is intimately linked to metabolic functions such as protein synthesis, glucose uptake, ATP production, nutrient transport, autophagy and cellular growth $(96,97)$, recent publications have identified novel effects of chronic GLP-1R stimulation which impact these pathways. For instance, GLP$1 \mathrm{R}$ agonists have been reported to promote secretion of insulin like growth factor-2 (IGF-2), and induced expression of its receptor (IGF1-R), which once stimulated activate downstream cascades including the PI3K/AKT as well as the cellular growth and proliferative mitogen-activated protein kinase (MAPK) pathway $(19,20,98)$. The biosynthesis, secretion and subsequent activation of the IGF-2/IGF-1R autocrine loop is significantly enhanced by the presence of glutamine, and has been reported to protect $\beta$-cells against apoptosis, and increases $\beta$-cell glucose competence $(20,98,99)$. However, whilst this autocrine loop stimulates PI3K/AKT activity and contribute to some of the prosurvival abilities of GLP-1 in $\beta$-cells, it does not seem to mediate the enhanced metabolic phenotype induced by chronic exposure to GLP-1R agonism. Rowlands et al. demonstrated that neither functional inactivation of IGF-2 nor silencing of its receptor by siRNA could mitigate the observed metabolic adaptations enacted by prolonged exposure to Exendin-4 (19). Thus, as the mitochondria and ER form structural and functional networks, the ability of GLP-1 to enhance metabolism may reduce ER stress by enhancing mitochondrial derived ATP and $\mathrm{Ca}^{2+}$ for utilization in the maintenance of ER homeostasis $(46,100,101)$. Through elevation of cytosolic and intra-mitochondrial $\mathrm{Ca}^{2+}$, and mobilization of intracellular $\mathrm{Ca}^{2+}$, GLP-1 may mitigate the required $\mathrm{Ca}^{2+}$ transfer from ER to mitochondria, thereby sustaining mechanisms which facilitate protein folding (102104). Therefore, we hypothesize that metabolic reprogramming in $\beta$-cells underlies the protective effects of GLP-1 under various stress conditions. In this scenario, enhanced metabolism can provide additional energy required to facilitate stress response and pro-survival mechanisms utilized by $\beta$-cells during challenging physiological conditions.

Although primarily studied in the pancreatic $\beta$-cell, the beneficial effects of GLP-1 and its analogs have recently been shown to be advantageous to a variety of tissues in several disease pathologies, such as the heart, liver, lung, muscle, and brain, as detailed below in the following sections. It remains to be clarified, however, as to whether the metabolic and pro-survival responses arising from chronic GLP-1R mediated signaling cascades are relevant to extra-pancreatic tissues as well.

\section{GLP-1 ACTION IN OTHER TISSUES}

\section{Skeletal Muscle}

Beneficial actions of GLP-1 differ between, skeletal, smooth and cardiac muscle, and again between the two subsets of smooth muscle, single and multi-unit cells (gastrointestinal/urogenital and vasculature cells, respectively) (105). Due to its ability to act on numerous pathways that can regulate glycaemia, weight, lipid metabolism, and blood pressure (Figure 2) (1,29), as further outlined below, GLP-1R agonists, have been implicated and implemented as a potential therapy to address the increasingly prevalent pathologies associated with metabolic syndrome.

Studies assessing GLP-1's extra-pancreatic effects, such as its insulin-like actions, revealed that exposure of skeletal muscle to GLP-1R agonists enhanced glycogen synthesis, glycogen synthase $\alpha(\mathrm{GS} \alpha)$ activity, glucose metabolism and inhibited glycogen phosphorylase $\alpha$ activity in diabetic and non-diabetic rodent models, and human tissue (106-109). Interestingly, compelling evidence suggests that such muscle effects are independent of cAMP signaling. This was observed in rat and human muscle cells, but also in studies conducted in hepatocytes and adipocytes, potentially utilizing inositol phosphoglycans (IPGs) as the intracellular second messenger $(108,110,111)$. While the amino acid sequence, same as that of the pancreatic GLP$1 \mathrm{R}$, has been identified in multiple tissues (112), these studies identified that GLP-1 acted through a unique receptor distinct from that of the $\beta$-cell, which allowed this deviation from the canonical signaling of GLP-1. Whether this deviation from the non-canonical effects of the GLP-1R in muscle tissue are resultant from alternative splicing, the widespread hetero dimerization of B-family GPCRs, variations in ligand-receptor interactions or GLP-1 degradation products still requires further investigation (113-115).

To date, understanding of GLP-1 effects in skeletal muscle has mostly stemmed from the laboratory of VillanueveaPenacarillo, who have revealed that GLP-1R agonists can induce PI3K/PKB (Akt), P44/P42 MAPK, p70S6K, and Protein kinase C (PKC) signaling pathways in skeletal muscle cells (116-119). Corroborating this findings, similar results were obtained in L6 myotubes and 3T3-adipocytes, that Exendin-4 promoted a PI3K dependent increase in insulin-stimulated glucose uptake (120). Other lines of evidence suggest that GLP-1R activation promotes skeletal muscle glucose transport independent of insulin through the AMPK signaling pathway and downstream activation of TBC1D1, a paralog of the phosphorylated Akt substrate AS160, thereby leading to translocation of GLUT4 to the plasma membrane (121-124). Akt is the canonical mediator of insulin-induced GLUT4 translocation. Although, it should be noted that the difference in signaling pathways from these latest studies may result from the extended duration of exposure to the GLP-1R agonist $(122,123)$. Interestingly, two of the above mentioned papers reported a rise in cAMP measured in muscle cells, as well as an increase in PKA contributing to a favorable metabolic phenotype in the studied muscle cells $(121,123)$. One 


\section{Muscle}

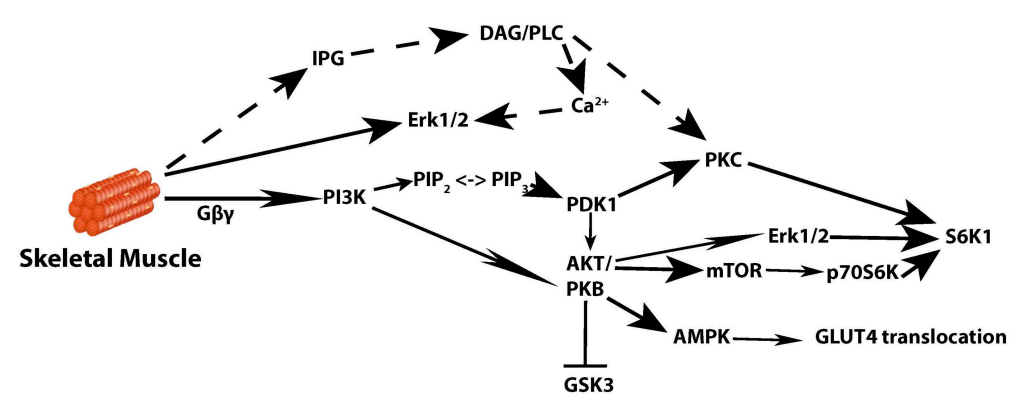

$\uparrow$ Microvasculature recruitment

Glucose catabolism

Glycogen Synthesis

Glucose Utilization

Lipid Storage

De novo cholesterol synthesis

$\mathrm{Ca}^{2+}$ Transfer from ER

Oxygen Consumption

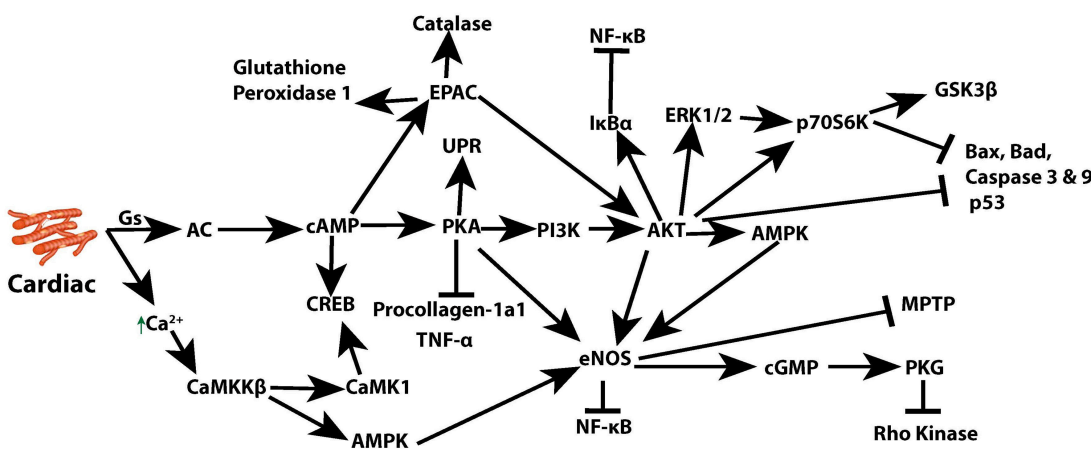

$\uparrow$ Cardiac function

Coronary Flow

Heart Rate

eNOS

Glucose Uptake

Cytoprotection

$\uparrow$ ANP

RISK/SAFE signalling

ER homeostasis

Cell swelling

Cytoskeleton disintegration

Infarct Size

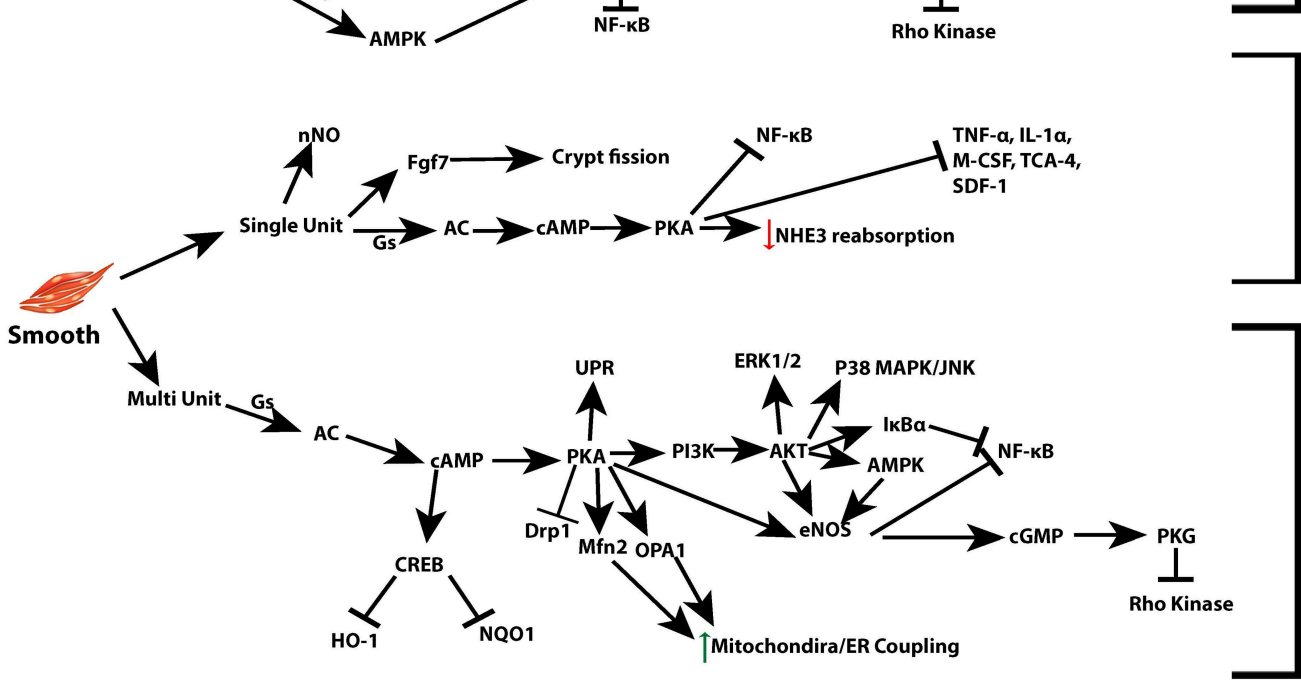

Stabilization of Renal blood flow Stabilization of Urinary Flow rates

Renal interstiitla fluids

Glomerular Filtration rate

Gastric Emptying

Nutrient absorption

IBS induced pain

Gut Inflammation
Gar

FIGURE 2 | GLP-1 signaling across different muscle types. Multiple signal transduction pathways and their net impact arising from GLP-1R stimulation in skeletal, cardiac, and both multi and single unit smooth muscle.

possible explanation for these findings may be that, as in neurons and sperm, increases in cAMP could be a result of enhanced $\mathrm{Ca}^{2+}$ or even calcium/calmodulin-dependent protein kinase II activity which in turn can activate AC (125-128). While the ability for GLP-1 to impact skeletal muscle in regards to glucose catabolism and glycogen synthesis has been analyzed in depth, further mechanistic studies are required to fully elucidate the role for incretin hormones in regard to this tissue type.

\section{Smooth Muscle and Vascular Tissue}

Recent studies have described receptor dependent and independent effects of GLP-1 in smooth muscle, whereby exposure to physiological concentrations of acutely infused GLP-1 can relax conduit arteries in healthy humans, and recruit skeletal and cardiac muscle microvasculature. Dilatation of microvessels can facilitate insulin and nutrient delivery, tissue oxygenation, and glucose utilization $(129,130)$. This dilatory 
effect is believed to occur as a result of GLP-1 binding to the abundantly expressed, endothelial cell GLP-1R, triggering a downstream signaling cascade resulting in microvasculature recruitment via a NO-dependent mechanism $(129,131,132)$. Additionally, the effect of the GLP-1 analog Liraglutide on endothelial cells has been evaluated in cultured human umbilical vein endothelial cells (HUVECS) to evaluate its impact on ER stress and apoptosis induced following overnight exposure to high glucose (133). The authors found that such treatment reduced apoptosis and ER stress through a mechanism which likely involves stimulation of the nuclear-encoded mitochondrial protein optic atrophy protein 1 (OPA1). It appears that the ability for GLP-1 to modulate mitochondrial metabolism is not limited to the $\beta$-cells. Indeed Morales et al. (134) reported that GLP-1 treatment stimulates mitochondrial activity in A7r6 vascular smooth muscle cells through recruitment of the ER to the mitochondria via the tethering protein Mitofusin-2 (Mfn-2). Enhanced Mfn-2 promotes ER-mitochondria co-localization and increases $\mathrm{Ca}^{2+}$ transfer from ER to the mitochondria, thus facilitating high demand for oxygen consumption and ATP production.

Studies conducted in rodent models have shown that stimulation of the GLP-1R led to changes in blood pressure (BP), depending on experimental model $(29,135,136)$. In humans, one study reported an increase in BP over $2 \mathrm{~h}$ from healthy subjects following a single administration of GLP-1 (136), while another reported that chronic administration of GLP-1 analogs to patients with metabolic syndrome led to a reduction in BP [reviewed in $(29,137,138)]$. Such conflicting results may result from complex actions of GLP-1 on vascular smooth muscle and cardiac tissues in combination with its effects in the autonomic nervous system. Altogether GLP-1's multi-tissue actions can mediate alterations in BP, vasodilation and constriction, body weight, and heart rate (120). Nevertheless, the short- and long-term effects of GLP-1 on vascular smooth muscle are not completely understood and thus require further examination to ensure GLP-1 therapies can be utilized to their utmost potential.

Another mechanism by which GLP-1 therapies have been utilized to attenuate or partially attenuate metabolic syndrome is through their impact on diet and satiety $(29,130,133,139,140)$. Notably, GLP-1's action on gastric emptying has been indicated to be enacted by reduced contraction in human intestinal muscles, and it occurs as a direct result of activation GLP-1R in the gastrointestinal (GI) tract (140), rather than for its ability to mitigate food motivated behavior through receptor activation in the hypothalamus or the hindbrain (141). However, the effects on gastric emptying appear to be short acting, since clinical studies and animal models of chronic administration of GLP-1R activators altogether suggest a negligible effect on long-term gastric emptying. Instead, evidence suggests that reduced weight gain occurs through direct actions on the pancreas, as well as through reduction of appetite mediated by central nervous system responses (141-143). Reducing the rate of gastric emptying, however, does not just impact satiety, but also delays the rate of entry of nutrients into the small intestine and their subsequent absorption, which therefore influence postprandial glucose metabolism, hormonal responses, and ultimately enhances GLP-1's anti-diabetogenic effects (144, 145). Slowing of small bowel motility was reported to occur in a GLP-1R and nitric oxide (NO) dependent manner, independently of both somatostatin and insulin, in fasting but not fed rats (146). Such effects have been reported in healthy (147), obese (148), diabetic (149), and critically ill human subjects (150). While gastric relaxation and postprandial gastric accommodation were reported to be mediated by vagal cholinergic pathways (151153). Work by Amato et al. (154) validated these findings by demonstrating that acute administration of GLP-1 activated the GLP-1R in human colon cells and resulted in an inhibitory effect on large intestine motility through release of neural NO.

\section{Kidneys}

A broad array of renoprotective properties have been reported from GLP-1 therapies. Positive effects in the renal tissue were observed both in diabetic and non-diabetic models of chronic kidney disease (CKD), as well as acute kidney injury (AKI) (155160). Although not often considered as part of the metabolic syndrome, accumulating evidence has begun unearthing a link between the increasing morbidity and mortality rate in patients with kidney disease and metabolic syndrome (156, 159, 161, 162). This entwinement of kidney disease and metabolic syndrome complicates investigations with GLP-1 therapies due to the indirect benefits GLP-1R agonist therapies have on other tissues including but not limited to alterations in BP, glucose homeostasis, weight loss and insulin levels [reviewed in (155, $156,161,163)]$. Adding to this scenario is the lack of agreement regarding the exact locality of GLP-1R expression in the kidney $(1,164)$, although it is generally accepted that in humans and rodents the GLP-1R is expressed in the renal vasculature and afferent arterioles, with some studies reporting receptor expression in the proximal tube and glomerular capillary, but not in the distal tubules $(155,165-168)$. It is evident from both clinical and animal studies that GLP-1 based therapies are beneficial to kidney function through increases in renal blood flow $(\mathrm{RBF})$, urinary flow rate, prevention of rises in plasma creatinine, reduced tubular necrosis, an increase in renal interstitial fluids and glomerular filtration rate (GFR), as well as cytoprotective and anti-inflammatory actions $(160,161,164,166$, 169, 170).

GLP-1R agonists are believed to cause these effects in the kidney through both direct kidney based GLP-1R activation, and indirect receptor actions, potentially through interactions with the nervous system (170), the renin angiotensin system (RAS) (155, 171-173), and regulation of atrial natriuretic peptide (ANP), a blood pressure and electrolyte regulator (173). Regardless of this lack of consensus in terms of indirect kidney responses to GLP-1 therapies, the direct actions of GLP-1R activation in the renal tissue are consistent. Acute exposure increases the diuretic and natriuretic excretion rate, which is in part dependent on inhibition of $\mathrm{NaHCO}_{3}$ reabsorption via a cAMP/PKA modulation of NHE3 (renal cortical $\mathrm{Na}^{+} / \mathrm{H}^{+}$ exchanger isotope 3) (166, 169). Furthering this, GLP-1's renal hemodynamic actions have been observed to alter GFR, potentially to regulate the filtered electrolyte load and volume $(159,174)$. In this sense, Exenatide acutely increased GFR 
and suppressed proximal tubular reabsorption in Wistar rats, resulting in approximate doubled early distal flow rate (175). Altogether these finding imply that Exenatide works as a diuretic at the kidney level. Similar results have been recently reported in humans (176).

Activation of the GLP-1R/cAMP/PKA pathway is also crucial in renal protection, with studies in a range of rodent models reporting a reduction in renal inflammation, renal fibrosis, and decrease in renal oxidative stress arising from the toxic milieu induced in metabolic syndrome $(158,161,166,177,178)$. These pro-survival abilities are believed to arise from enhanced GLP-1 signaling leading to a reduced expression of the pro apoptotic markers caspase-3, and Bax/Bcl-2 (158), as well as reducing oxidative stress through increased expression of the oxidative defense gene heme oxygenease-1 (HO-1) $(160,178)$, and inhibition of NAD(P)H oxidase in a cAMP/PKA dependent manner (166). Activation of the GLP-1R signaling pathway has also been reported to reduce macrophage infiltration, potentially alleviating the associated increase in ROS and inflammation, as well as attenuating the progression of renal fibrosis through downregulation of ERK1/2 and its upstream activator transforming growth factor-beta 1 (TGF- $\beta 1$ ) (160, 177). Despite these results, further studies are still required to fully elucidate the molecular mechanisms that mediate the reported attenuation in apoptotic and inflammatory pathways, particularly as accumulating clinical evidence highlights the potential of GLP-1R agonist therapies in DKD, ultimately urging for deeper understanding of cellular actions of these analogs in the renal tissue [reviewed in $(156,157,159,162,179)]$.

\section{Adipose Tissue}

Although GLP-1 based therapies primarily aid weight loss through satiety, their usefulness is further extended by multiple studies implicating GLP-1R agonists as regulators of adipogenesis. Studies have indicated that GLP-1 based therapies can potentially influence whole body energy metabolism through their regulation of adipocyte development, acceleration of plasma clearance of glucose and triacylglycerol derived fatty acids, improvement of insulin signaling and stimulation of brown adipose tissue (BAT) thermogenesis (31, 142, 180184). The GLP-1R in adipocytes was reported to activate the $\mathrm{AC} / \mathrm{cAMP}$ signaling pathway, regulating apoptosis and preadipocyte proliferation through various cell signaling cascades including ERK, PKC and AKT, as well-altering the expression of peroxisome proliferator-activated receptor gamma (PPAR $\gamma)$ and its target genes $(142,185)$. GLP-1 may also act through a brain-adipocyte axis to modulate lipid metabolism in BAT, as well as white adipose tissue (WAT). In various rodent models, administration of GLP-1R agonists induced BAT thermogenesis through increased uncoupling protein 1 (UCP1), mitochondrial respiratory chain element Cox4i1 (Cytochrome C Oxidase Subunit 4I1) and PGC1 $\alpha$, independent of nutrient intake, as well as altering the expression of transcription factors involved in de novo lipogenesis $(123,181,186)$. Interestingly, GLP-1 has also been shown to activate Adipose-resident invariant natural killer $\mathrm{T}$ (iNKT) cells, triggering fibroblast growth factor 21 (FGF21), a major player in iNKT cell induced weight loss (187).
While still in its infancy, and convoluted by the various interconnected pathways, studies investigating the effects of GLP1 therapies in the adipose tissue of patients with obesity show promise, with trials replicating in vitro studies, and indicating a potential long term benefit of GLP-1R agonists therapies also in this important tissue. Deeper studies into the underlying mechanisms are warranted in order to specifically identify direct actions of GLP-1 agonists in BAT and WAT physiology and lipid metabolism.

\section{Heart}

Given that both T2D and obesity represent important risk factors for cardiovascular disease (CVD), there is emerging interest to establish the potential cardiovascular benefits of GLP-1R stimulation. Even though the positive effects of GLP1 analog therapies on the metabolic conditions described above could theoretically improve CVD outcomes, mounting evidence points that GLP-1 can also influence the cardiac tissue through direct receptor mediated responses. Indeed, it is recognized that the classical response initiated by GLP$1 \mathrm{R}$ activation leads to facilitation of cardiac function through enhanced glucose uptake, improved coronary flow, and in mice, secretion of atrial natriuretic peptide (ANP), a blood pressure and electrolyte regulator (163, 173, 188). However, studies to define the mechanism through which GLP-1 directly influences cardiac tissue are complicated by its broad actions in other tissues, such as blood vessels. For instance, a study conducted by Mells et al. (189) indicated that liraglutide treatment was able to reverse BP increases and cardiac hypotrophy resulting from a high fat diet (HFD) induced obese mouse model. The study, however, did not dwell further into the underlying mechanisms, making it particularly difficult to distinguish between the direct effects of the treatment in the cardiac muscle from those emanating from other tissues. Recent data published by the Drucker Laboratory and colleagues have indicated that some of the contrasting results of GLP-1 on the cardiovascular system in regards to both increasing and decreasing heart rates, and BP, are partially mediated by neurological signaling (120). Remarkably, in studies where the GLP-1R was conditionally disrupted only in mice cardiomyocytes (GLP- $1 \mathrm{R}^{\mathrm{CM}-/-}$ ), pre-treatment with liraglutide could still promote cardioprotection, increased survival and reduced infarct size following ischemia-reperfusion injury, suggesting these outcomes are not mediated directly by cardiomyocyte GLP-1R activity (190). Glucagon-like peptide (GLP)-1 (9-36) amide-mediated cytoprotection in ischemicperfused mice was blocked by the GLP-1R antagonist exendin9-39 but did not require the known GLP-1 receptor (190-193). Thus, the direct and indirect mechanisms which underpin the beneficial effects of GLP-1R agonism on cardiac injury remain to be clarified.

In an effort to address these gaps in knowledge, multiple groups have endeavored to define the role of GLP-1, its analogs, and related peptides $(11,194)$, in protecting cardiomyocytes and endothelial cells from injury. Indeed, GLP-1R activation leads to the re-establishment of ER homoeostasis, cytoprotection, and 
restoration of signaling pathways disrupted by diverse stress stimuli $(139,191,192,195)$. For example, liraglutide treatment corrected the decreases in eNOS, the endothelial nitric oxide synthase, responsible for most of the vascular nitric oxide production in a HFD model of cardiac dysfunction in mice (195). This is of particular importance as NO is crucial in a pathway that regulates the synthesis of the ubiquitous intracellular secondmessenger cyclic guanosine $3^{\prime}, 5^{\prime}$-monophosphate (cGMP). It has been reported that cGMP can activate two types of effector molecules in cardiovascular system, cGMP-dependent protein kinases (PKGs) and phosphodiesterases (PDE), which can stimulate cellular proliferation, mediate vaso-relaxation, and inhibit hypertrophy (196). Importantly, the effects in eNOS were accompanied by significant decreases in cardiac tissue TNF expression and NFKB activation (195). These effects were confirmed to be direct actions of the GLP-1R agonist in heart and vascular tissues since liraglutide also prevented palmitate-induced lipotoxicity in isolated mouse cardiomyocytes and primary human coronary smooth muscle cells in vitro. Together these data indicate that GLP-1R activation can activate multiple complementary protective and pro-survival mechanisms in cardiac cells, and endothelial cells. These findings are further supported by larger animal trials in which GLP-1 induced reduction in infarct size after ischemia-reperfusion (IR) injury (197), improved left ventricular function, and altered heart rate and BP when infused into dogs with pacing-induced cardiomyopathy (198). Furthermore, GLP-1 is hypothesized to activate ischemic conditioning (IC) through reperfusion injury survival kinase (RISK) and survivor-activating factor enhancement (SAFE) pathways (199, 200). Activation of this conditioning pathway post GLP-1R stimulation has been shown to reduce infarct size, improve cardiac function and enhance AKT activation and Bcl-2, an important anti-apoptotic protein, expression after IR injury in pigs (201). IC is interconnected with the mitochondrial KATP channel (mK-ATP) $(202,203)$ as well as the ATP derived metabolite adenosine, which activates the adenosine receptor and its signaling pathway leading to ischemic preconditioning $(193,204,205)$. Although still unclear, the role of GLP-1R signaling cascades in the activation of conditioning pathways may include hijacking these subcellular pathways. Furthering this, the GLP-1 mediated relaxation of ex vivo rat aorta described by Green et al. (194), was lost upon K-ATP channel blockage, indicating a link between GLP-1R activation induced IC.

Initial human trials mimicked cellular and animal model studies, with GLP-1 therapies improving left ventricular (LV) function in patients with acute myocardial infraction (AMI) and serve systolic dysfunction (206). The promising results of this pilot study were followed in 2006 by an additional study demonstrating that chronic GLP-1 infusion over 5 weeks can improve LV function and quality of life in diabetic and non-diabetic participants (207). As these improvements were seen in both diabetic and non-diabetic groups, glycemic control in the GLP-1 treated group was deemed not to be a contributing factor to the beneficial effects. Since these early studies, treatment with GLP-1 analogs has been noted to improve hemodynamic recovery in patients undergoing coronary artery bypass grafting (208), protect against ischemic LV dysfunction (209), prevent hyperglycemia during cardiac surgery (210) and reduce reperfusion injury (211-213). Finally, data from recent large scale cardiovascular outcomes in T2DM trials revealed a significant reduction in cardiovascular death rates in GLP-1 analog treated patients $(214,215)$. Research into GLP- 1 therapies on cardiac tissue continues to represent an expanding field, with the potential for a broad range of therapeutic applications beyond cardiovascular outcomes to be realized through an understanding of the underlying mechanism of action.

\section{Liver}

Of the body's organs, levels of GLP-1 are recognized to be highest in the liver owing to transport of the incretin through the hepatic portal vein. The therapeutic effect of GLP-1 and its analogs on restoring hepatic function impaired by a variety of insults is supported by in vivo and in vitro studies (27, 216). Changes induced from GLP-1 or its analogs, in the liver, regulate a variety of processes including, hepatic gluconeogenesis, glycogen synthesis, and glycolysis (Figure 3) (1, 216, 217). In rodent models, GLP-1R agonist based therapies have been reported to increase both glycogen and glycogen synthetase $\alpha$, through PI3K, PKC, PP-1 (type 1 protein phosphatase), pathways in isolated hepatocytes (218), as well as acting in an insulin-like manner to inhibit glucagon-induced glycogenolysis in perivenous hepatocytes (219). While the presence of the GLP-1R is still controversial in hepatocytes, GLP-1R expression at the protein level has indeed been reported in transformed human hepatocyte cell lines, $\mathrm{HuH7}$ and Hep-G2, as well as primary human hepatocytes (220). However, regardless of the presence of the receptor in hepatocytes, direct receptor-ligand mediated actions in the liver remain controversial with some research groups proposing that observed benefits are a result of receptor independent events (221-225). Mechanisms may include GLP-1 degradation products GLP-19-36, GLP-1 $128-36$ or GLP-1 $1_{32-36}$ which may be transported through the plasma membrane without the involvement of a receptor, and activate AC and Wnt signaling [reviewed in (226)].

To date, studies in animals and humans have provided evidence for the potential of Liraglutide to improve hyperlipidemia, liver fibrosis and inflammation, non-alcoholic fatty liver disease (NAFLD), as well as reduce liver fat content in T2DM patients (227-230). Acute exposure of Sprague Dawley (SD) rats to GLP-1R activators controlled hepatic glucose production (HGP) through a gut-brain-liver neuronal axis, discussed later, involving GLP-1R stimulated duodenal mucosal PKC- $\delta$ activation (231). In this context, Exendin- 4 was found to inhibit key gluconeogenic enzymes and enhance hepatic insulin signaling. Exendin-4 was also reported to improve hepatic steatosis and insulin sensitivity in ob/ob mice, which was paralleled by reduction in oxidative stress and genes associated with fatty acid synthesis (232). Female APOE*3-Leiden.CETP mice, a model with human-like lipoprotein metabolism, were fed a cholesterol-containing diet and subsequently treated for 4 weeks with exendin-4. Utilizing a mouse model with human-like lipoprotein metabolism and western-type diet for 5 


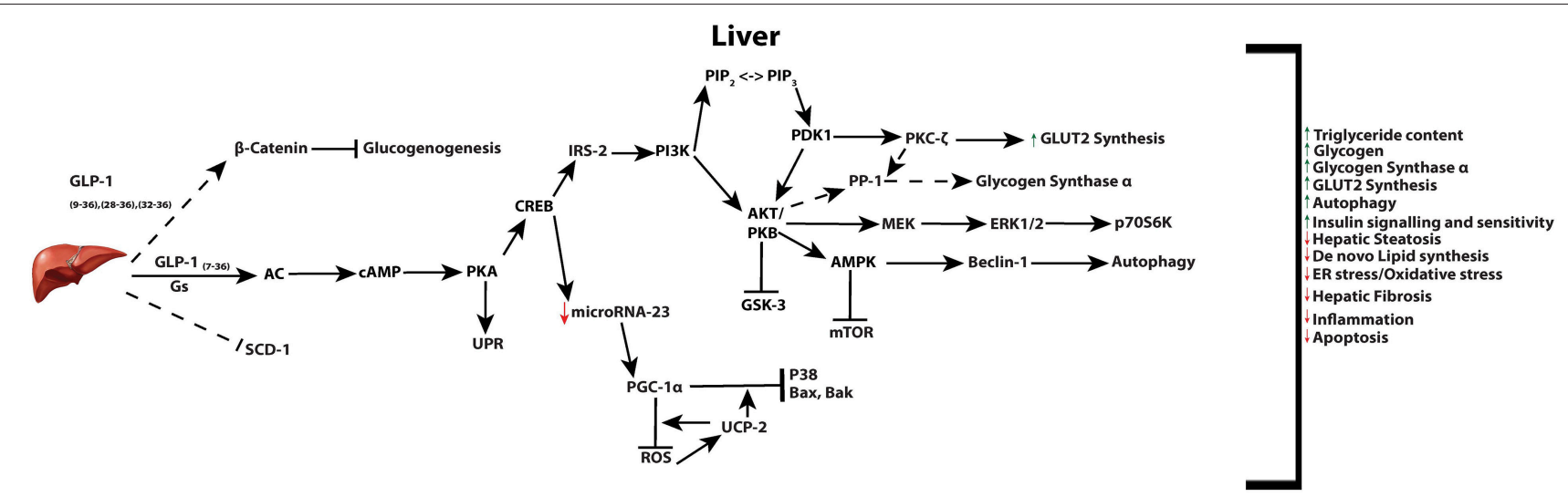

FIGURE 3 | Active GLP-1 and its truncated products signaling in the liver. Active GLP-1 and its cAMP dependent pathways (solid arrows), as well as hypothesized (dashed arrows) truncated product induced signaling and their respective net effects.

weeks to induce atherosclerosis, Exendin-4 treatment reduced inflammation within the liver and vessel well (233). Use of Exendin-4 in this mouse model limited the progression of hepatic inflammation and atherosclerosis through a reduction in macrophage influx and adhesion to the liver and vessel wall. These findings are further supported by a study revealing that GLP-1 analogs impact the production of triglyceride-rich lipoproteins in normoglycaemic men (234).

The hepatic actions of GLP-1 may be mediated through signal transduction of the AMPK/mTOR pathway. This was reported in a study showing that improvement of hepatocyte steatosis by liraglutide involves autophagy and its controlling AMPK/mTOR pathways (235). By inducing autophagy, GLP-1 therapies can relief the burden in the ER, reduce ER-stress, and subsequent hepatocyte apoptosis (236). Understanding the impact of GLP-1 treatments on the liver is crucial, as perturbations to both cellular lipid and very-low-density lipoprotein (VLDL) metabolism are associated with development of hepatic insulin resistance, obesity and diabetes. Recently, chronic stimulation of the GLP-1R led to increases in the mitochondrial uncoupling protein 2 (UCP2), an anti-mitochondrial oxidative stress gene, and the master mitochondrial biogenesis regulator and protective gene, peroxisome proliferator activated receptor-gamma coactivator $1 \alpha$ (PGC-1 $\alpha)$ (237). Such gene expression changes were hypothesized to be mediated through downregulation of the microRNA-23 and result in improved hepatocyte survival through reduction in mitochondrial ROS production, inhibition of P38 activity, and decrease in expression of apoptotic genes Bak and Bax $(237,238)$. Combined with previous knowledge that PGC- $1 \alpha$ and UPC2, play critical roles in mitochondrial metabolism (239), these data provide additional support for the hypothesis that the improved metabolism resultant from GLP-1R stimulation underlies the pro-survival abilities of GLP-1 signaling pathways.

\section{Brain}

GLP-1 and its receptor agonists are able to influence a variety of brain functions, including but not limited to: satiety, thermogenesis, blood pressure, neurogenesis, neurodegeneration, retinal repair, and altering energy homeostasis (Figure 4) (26, 30, 240-245). The GLP-1R is expressed in cells of the cerebral cortex, hypothalamus, hippocampus, thalamus, substantia nigra, circumventricular organ (CVO), cerebellum, and brainstem nucleus. This pattern of gene expression in the nervous system is evident in rodent, non-human primates, as well as humans (26, 241, 242, 244, 246248). Studies with mice have identified the source of GLP-1 to derive from preproglucagon neurons of the nucleus of the solitary tract within the brainstem (249). These neurons project to the thalamus, hypothalamus and cortical regions, and induce the release of GLP-1 by various stimuli in a mechanism similar to L-cells of the small intestine (30, 31, 240, 243). Gut-derived GLP1 can cross the blood brain barrier $(\mathrm{BBB})$ and bind receptors in the circumventricular organs of the brainstem, however its short half-life is believed to limit its function within the brain. Instead, it most likely influence the brain indirectly, through vagal nerve fibers in the enteric area, whereby it transmits metabolic information to the nucleus of the solitary tract (NTS) - neurons responsible to control brain regions known to mediate feeding behavior (250). Recent research has revealed that GLP-1 analogs, due to their extended half-lives, can reach the BBB and have distinct effects to endogenous GLP-1 in the brain $(26,250)$. These effects include the well-investigated anorexigenic effects, outlined below, as well as a range of neuroprotective abilities that have led to the use of GLP-1R agonists as therapies in human trials for a range of neurodegenerative diseases as discussed in detail further below.

Studies in rats using intracerebroventicular (icv) administration of GLP-1 or its analog Exendin-4, alone or in combination with the receptor antagonist Exendin (9-39), have shown that activation of the GLP-1R inhibits food intake and weight gain; such effects are attributed to changes in brain controlled hormone secretion (251-254). Similar findings have been recapitulated in studies of obesity in humans, and have highlighted GLP-1 based therapies as potential anti-obesity treatments. The role for GLP-1 signaling in satiety is understood to be a consequence of GLP-1R signaling attenuating the release of the orexigenic neuropeptides Neuropeptide Y (NPY) 


\section{BRAIN}

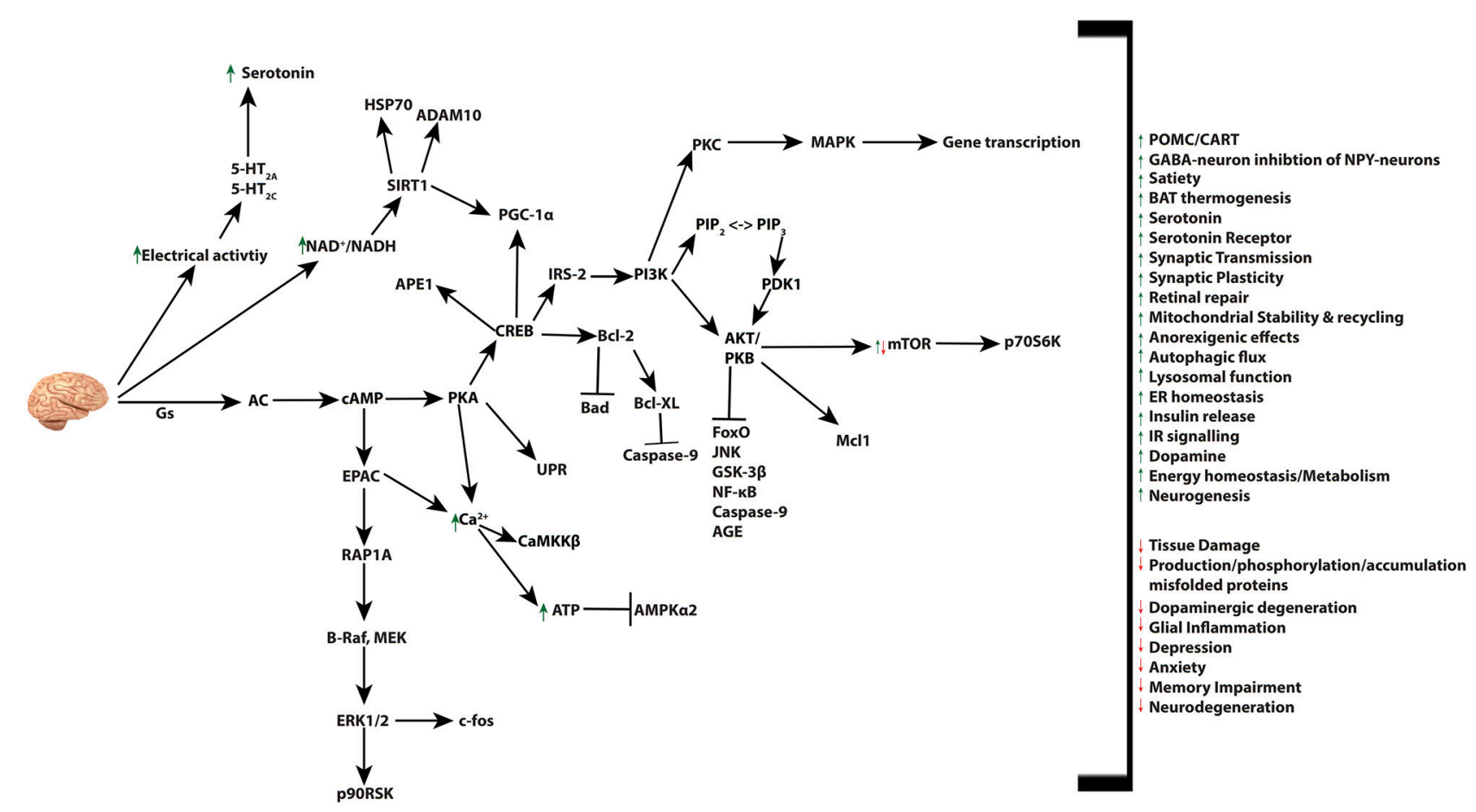

FIGURE 4 | Pleiotropic effects of GLP-1 signaling in the brain. GLP-1 and its analogs activate diverse signaling pathways in the brain, leading to a plethora of neuroprotective outcomes.

and agouti-related peptide (AgRP), as well as promoting the anorexigenic neuropeptides pro-opiomelanocortin (POMC) and cocaine- and amphetamine-regulated transcript (CART) (250, 254-256). These neuropeptides are produced by arcuate nucleus of the hypothalamus (ARC), a critical regulator of energy balance, feeding behavior, and body weight $(257,258)$. GLP-1 is believed to alter food intake through this pathway, with an acute receptor induced modulation of AMPK activity in the hypothalamus. Secher et al. (259), supports these findings, but also discovered that while the GLP-1 analog Liraglutide directly stimulates POMC/CART neurons, it indirectly inhibits NPY/AgRP neurotransmission via GABA-dependent signaling. This liraglutide induced weight loss, altered food intake and conditioned taste aversion occurs through CNS receptors rather than the vagus nerve, area postrema, paraventricular nucleus, or visceral nerves $(259,260)$. Novel data has recently surfaced proposing that activation of astrocyte GLP-1Rs may play a role in energy balance in the CNS and GLP-1s anorectic effect, although the mechanics underlying this new finding still require deeper investigation (261). Furthermore, native GLP-1 infusions in the CNS, have been shown to modulate thermogenesis of BAT, via enhanced sympathetic nervous system (SNS) activity (183). Both chronic and acute CNS infused GLP-1 promoted BAT activation and subsequently glucose and triglyceride uptake, via activation of AMPK in the hypothalamic ventromedial nucleus in rodents
$(181,182)$. GLP-1 is also able to upregulate alternatively activated (M2) macrophage-related molecules in human monocytederived macrophages (HMDM). This M2 macrophage activation enhanced production of anti-inflammatory factors was also found noted to enhance adiponectin secretion from adipocytes and derived from GLP-1 induced activation of the activator of transcription 3 (STAT3) which can further contribute to its protective abilities against metabolic syndrome (262). More recently, GLP-1 and its analogs have been shown to act in the dorsal raphe, whereby GLP-1R activation alters serotonin turnover and the 5-hydroxytryptamine $2 \mathrm{~A}\left(5-\mathrm{HT}_{2 \mathrm{~A}}\right)$ and 5$\mathrm{HT}_{2 \mathrm{c}}$ serotonin receptors in rats (263). Dorsal Raphe GLP-1R stimulation induces hypophagia and increases the electrical activity of the serotonin neurons in this region, indicating that serotonin may be a new neural substrate for GLP-1 activity and aid GLP-1s ability to reduce appetite, and body weight through bioenergetics metabolism (263). Whilst the ability of GLP-1 and its analogs to stimulate serotonin receptors in humans has yet to be tested, various studies have employed neuroimaging techniques, such as functional magnetic resonance imaging (fMRI) to assess GLP-1 actions in human brain. These studies recapitulated animal studies, where infusion of GLP-1 analogs was found to; attenuate neuronal activity in reward processing areas, reduce appetite and hedonic feeding in healthy volunteers (264), as well as obese and T2DM patients 
$(265,266)$. Whilst weight loss as a result of GLP-1 therapies in humans is believed to be primarily resultant from their inhibitory effect on food intake; distinct neuronal responses should be taken into account when investigating the effects of GLP-1 in neurodegenerative diseases. Chronic inflammation of the brain is a known pathophysiological hallmark of various neurodegenerative diseases, including Alzheimer's disease (AD), multiple sclerosis (MS), and Parkinson's disease (PD), all demonstrated in animal models to benefit from GLP-1 mimetics therapy $(14,26,30)$.

Mental illnesses and neurodegenerative diseases not only negatively impact on a patient's quality of life through their impairment of motor functions, they can enhance dementia and depression, which are often refractory to treatment (267). This resistance to treatment may be influenced by accumulating evidence that implicates a link between neural inflammation and the pathology of depression $(268,269)$. In addition, analysis of patients with psychiatric illnesses has revealed an alteration to crucial intracellular signaling pathways including the AKT/GSK3 (glycogen synthase kinase) pathway $(269,270)$. This data along with observation that GLP-1R signaling enhanced levels of serotonin, dopamine (DA), and their receptors $(263,271)$, has potentiated the use of GLP-1R agonists as a management strategy for mental illness and neurodegenerative diseases. While initial in vitro studies have begun to reveal the mechanistic effects of GLP-1 in regards to neurodegenerative diseases, as outlined further below, both animal and human trials have already taken advantage of GLP-1's beneficial actions. Several animal studies have been undertaken with two studies showing that chronic treatment in rats is associated with reversal of depression-like behavior and acute treatment induced anxiety-like behavior $(270,272)$, while an alternate study indicated no GLP-1 induced changes in either behavior (273). Such contrasting results raise caution in the design and implementation of human trials which evaluate the therapeutic effects of GLP-1 and its analogies in the treatment of neurodegenerative diseases.

Although several recent studies have begun to elucidate the impact of GLP-1 analog therapies on the progress of neurodegenerative disorders, no human clinical trials have directly measured the impact of GLP-1 analog therapies on mental health disorders. Despite this, several trials using GLP1 analogs for T2DM have a battery of neuropsychological tests as secondary outcome measures that may provide insights into GLP-1's impact on mental illness (274). Whilst many studies are still underway, only one recent clinical study analyzing the effect of the liraglutide analog in regards to Alzheimer's disease has been reported (NCT01469351) (275), and two clinical trials and one population based nested casecontrol study assessing Parkinson's Disease and GLP-1R activity (NCT01971242, NCT01174810) (28, 267, 276-278). Findings from the AD study in Denmark indicated that GLP-1 analog treatment caused a slight, but non-significant increase in cerebral glucose metabolism $\left(\mathrm{CMR}_{\mathrm{glc}}\right)$ after 6 months of treatment (275). As a decline of $\mathrm{CMR}_{\text {glc }}$ correlates with cognitive impairment, synaptic dysfunction and evolution of the disease, GLP-1's slight reduction as noted in this study offers a potential mechanism of benefit. However, a large gap in regards to AD and GLP-1 based therapies remains, since the small sample size of the study precluded the ability for the study to determine if GLP-1 administration reduces amyloid $\beta(\mathrm{A} \beta)$ load or alter cognitive scores (275). Nevertheless, in PD, an initial study into GLP1 analog therapy, published in 2013, assigned 45 patients with moderate PD to receive subcutaneous Exenatide injections for 12 months alongside patient which did not receive any injection. Despite lacking a placebo-control in this study, the blinded ratings were indicative of clinical improvement in both motor and cognitive measures compared to control $(277,278)$. This study has since been expanded with a Swedish group assessing the effects of both GLP-1R agonists and DPP-4 inhibitors, and a UK based study opting for once weekly Exenatide treatments. The Swedish study, through use of a population-based nested case-control study, found a significantly decreased incidence of PD among individuals who had been recorded to take DPP4 inhibitors (276). This is in contrast to the UK based studies (NCT01971242 and NCT01971242) which noted a positive and persistent effect of Exenatide treatment in off-medication motor scores (267).

Given the promising results from clinical trials, an understanding the mechanisms underlying GLP-1 mimetic actions on normal and diseased neural tissue would be invaluable. Neurodegenerative diseases share several pathological features, including but not limited to, synaptic loss and failure, reduced neurogenesis, enhanced free radical production, and cell death [reviewed in (279-282)]. The accumulation of misfolded proteins, common in neurodegeneration, impairs cellular communication and function, and causes the activation of neuronal inflammatory responses by activation of glial cells (microglia and astrocytes). Although such neuroinflammatory responses initially maintain homeostasis, chronic activation leads to increased severity of the disease state (283-285). Fortunately, GLP-1 effects in the brain are reminiscent of its actions on pancreatic $\beta$-cells, signaling through GLP-1R to initiate anti-inflammatory, anti-apoptotic and pro-survival effects $(250,286,287)$.

The pro-survival effects of GLP-1 on neurons are attributable to the reduction of ER-stress and enhanced autophagy in neural cells. Studies by Panagaki et al. (288) as well as Chen et al. (289) reported that liraglutide enhanced AKT signaling and STAT3 activation, resulting in reduced apoptosis. These effects can also arise from activation of GLP-1R in astrocytes and microglia (290), which when triggered can reduce the levels of pro-inflammatory cytokines such as TNF- $\alpha$ and IL- $1 \beta$ in different models of brain inflammation (290-293). In PD, chronic activation of microglia can trigger polarization toward the cytotoxic M1 macrophages, leading to a self-perpetuating persistent inflammatory environment $(294,295)$, considered to be a major factor in driving dopaminergic degeneration $(267,296$, 297). Use of Exenetide has been reported to halt dopaminergic degeneration and restore dopamine (DA) imbalance induced by 6-OHDA, MPTP, and Lipopolysaccharide in animal toxin models $(271,287,298)$. Although mechanism of action through which GLP-1 stimulates microglial function in regards to chronic inflammation remain unclear, several studies point to NF- $\kappa \mathrm{B}$ activation achieved through DPP-IV inhibitors in 
rotenone induced rodent PD models. Increased levels of NF- $\kappa \mathrm{B}$ are observed in tyrosine hydroxylase $(\mathrm{TH})$ and dopaminergic neurons, astrocytes and microglia, with implications on the pathogenesis of $\mathrm{PD}$; while inhibition of NF- $\kappa \mathrm{B}$ is correlated with neuroprotective effects in such PD models (299, 300). Since GLP-1 signaling activates AKT, one plausible explanation for its therapeutic effect in PD to reduce glial inflammation is through this increased activity in order to elevate levels of the Inhibitor of NF- $\kappa \mathrm{B}(\mathrm{I} \kappa \mathrm{B} \alpha)$, ultimately leading to a reduction in neuroinflammation $(26,301)$.

Extending from these findings, GLP-1 mimetics can also act upstream of chronic neuronal inflammatory responses in cells by ameliorating the accumulation of misfolded proteins. The accumulation of misfolded proteins can occur through dysregulation of key cellular process, which in turn adversely affects neuronal homeostasis $(267,302-305)$. GSK-3 $\alpha / \beta$ isoforms are an example of constitutively active key regulatory enzymes, which when recruited and activated, by $\alpha$-Synuclein ( $\alpha$-Syn) (a key mediator of PD), leads to hyperphosphorylation of Tau and subsequent increased accumulation of amyloid aggregates (306-309). Several in vivo and in vitro studies have showed that GLP-1 administration can protect neurons from $A \beta$ aggregation, advanced glycation end products (AGEs) insult, and reduce tau hyperphosphorylation through regulation of GSK-3 $\beta$ signaling. The proposed mechanism of action of GLP-1 is believed to occur through activation the PI3K/AKT signaling pathway, leading to phosphorylation and deactivation of GSK-3 $\beta$ amino-terminal serine residue $(271,302,310,311)$. As previously indicated, GLP-1R activation may reduce protein aggregation through autophagic clearance, however a study by Yuan et al. (312) in 2015 , indicated that rotenone induced alterations to autophagy and $\alpha$-Syn clearance, are mediated by $\mathrm{Ca}^{2+} / \mathrm{AKT} / \mathrm{GSK}-3 \beta$ signaling pathway. Particularly, the authors reported that rotenone treatment of $\mathrm{PC} 12$ cells (derived from a tumor of the rat adrenal medulla) increased intra-cellular $\mathrm{Ca}^{2+}$ which, in turn, induce aggregation and phosphorylation of $\alpha$-Syn and impair autophagy. While the hypothesis that raised intracellular $\mathrm{Ca}^{2+}$ promotes aggregation $\alpha$-Syn is supported by previous work (313), the claim that rotenone induced alterations to autophagy and $\alpha$-Syn, are mediated by $\mathrm{Ca}^{2+} / \mathrm{GSK}-3 \beta$ signaling pathway may be an oversimplified statement, but nonetheless, reveals an additional mechanism by which GLP-1R signaling can alleviate protein aggregation. As $\mathrm{Ca}^{2+}$ is a second messenger in the cell, inappropriate fluctuations would undoubtedly impact autophagy and protein aggregation, and through the use of rotenone, an inhibitor of mitochondrial complex I, leads to elevation of intracellular $\mathrm{Ca}^{2+}$ through inhibition of resting background $\mathrm{K}^{+}$ currents, membrane depolarization, and VDCC opening, This would in turn impact ATP production, inhibit AC activity, down regulate $\mathrm{CAMP}$ signaling, and disrupt mitochondrial membrane potential $(314,315)$. Changes in cellular ATP, and mitochondrial stability, induced by protein aggregation would not only promote apoptosis, but increase cellular ROS, and oxidative stress, all of which act together to contribute to the destabilization of ER homeostasis and autophagy in neurodegenerative diseases (314, 316-319). GLP-1R activation can act to mitigate the deleterious effects of overloaded intracellular $\mathrm{Ca}^{2+}$, as mentioned before, through the cAMP/PKA/EPAC pathways and is thought to be an integral mechanism in the prevention of spatial memory and hippocampal synaptic plasticity impairments arising from $\mathrm{A} \beta$ induced toxicity $(43,320,321)$. The GLP-1 mediated regulation of $\mathrm{Ca}^{2+}$ is also coupled to restoration of insulin signaling throughout the brain, which can further promote its pro-survival abilities. This is crucial as impaired insulin signaling in AD and PD patients has been reported to negatively impact dendritic sprouting, neuronal stem cell growth and tissue repair (322-324).

Within the brain, endogenous, brain derived GLP-1 can promote insulin release $(325,326)$, thereby potentially increasing the expression of the internalized IR and IGF-1R in AD patients. Such a mechanism has recently been reported to restore IR signaling deficits through decreases of the c-Jun N-terminal kinase (JNK) signaling in symptomatic (?) T2D mice (326). These studies are furthered in rodent models whereby both chronic and acute treatments of liraglutide have been shown to protect against $\mathrm{A} \beta$-induced impairment of memory and spatial learning in rats (315), as well as prevent memory impairment, reduce $\beta$ amyloid plaque, and plaque induced chronic inflammation in the APP/PS1 AD mice model $(315,327)$. AD rodent models chronically treated with the GLP-1 analog Val(8)glucagonlike peptide- 1 caused modulation of neurotransmitter release, synaptic transmission (LTP) formation, and restoration of synaptic plasticity, as well as preventing impairment in the learning of new spatial tasks (328-330). Restoration of IR signaling, acts synergistically with GLP-1 signaling, modulating autophagy, oxidative stress, protein synthesis, apoptosis, and mitochondrial biogenesis $(331,332)$. GLP-1's oxidative stress protective mechanisms are indicated to be ameliorated in primary cortical neurons by GLP-1/CREB signaling inducing expression of apurinic/apryimidinic endonuclease 1 (APE1), a key enzyme of the base excision DNA repair (BER) pathway (333), while also impacting protein aggregation induced neurotoxicity through enhanced mitochondrial function. This has been indicated to occur through the deacetylase SIRT1 (334), its promotion of heat shock protein 70 (HSP70), an augmenter of normal $\alpha$-Sync folding (335), modulation of PGC-1 $\alpha$, as well as activation of ADAM10, through retinoic acid receptor $\beta$, leading to the reduction of plaque formation (336).

It is evident that the mechanism through which GLP1 stimulates pro-survival signaling, reduces neural tissue inflammation and improves cognitive function is complex. However, by defining cell-type specific signaling pathways in neural cells, it may be possible to develop distinct treatment strategies that uniquely modulate GLP-1 signaling in mental illness as well as neurodegenerative diseases.

\section{CONCLUSIONS}

GLP-1 promotes glycemic control through a plethora of widely recognized physiological mechanisms. Among them, stimulation of insulin secretion and inhibition of glucagon release directly improve postprandial glucose homeostasis, while inhibition of gastric emptying and food intake represent a longer term positive 
effect of limiting weight gain. Due to these properties, GLP1 therapies have been routinely and successfully used for the treatment of T2D and obesity for more than a decade. Most recent studies unveiled that GLP-1 analogs also act in the CNS and various peripheral tissues to restore and maintain normal cellular functions. This has been demonstrated in response to a variety of distinct disease paradigms and physiological insults, either through direct cell autonomous effects or through indirect whole body metabolic improvements. In this review, we provided a thorough description of the diverse roles for GLP-1R signaling across multiple tissues, focusing in the downstream pathways stimulated by acute and chronic activation of the receptor, and discussed novel pleiotropic applications of GLP-1 mimetics in the treatment of human disease. Continuing efforts to delineate tissue specific mechanisms of GLP-1 action are necessary in order to identify novel translational alternatives and foster the development of new GLP-1-based therapeutic agents harnessing

\section{REFERENCES}

1. Campbell JE, Drucker DJ. Pharmacology, physiology, and mechanisms of incretin hormone action. Cell Metab. (2013) 17:819-37. doi: 10.1016/j.cmet.2013.04.008

2. Taylor SS, Buechler JA, Yonemoto, W. cAMP-dependent protein kinase: framework for a diverse family of regulatory enzymes. Annu Rev Biochem. (1990) 59:971-1005. doi: 10.1146/annurev.bi.59.070190.004543

3. Kashima Y, Miki T, Shibasaki T, Ozaki N, Miyazaki M, Yano H, et al. Critical role of cAMP-GEFII-Rim2 complex in incretin-potentiated insulin secretion. J Biol Chem. (2001) 276:46046-53. doi: 10.1074/jbc.M108378200

4. MacDonald PE, El-kholy W, Riedel MJ, Salapatek MF, Light PE, Wheeler MB. The multiple actions of GLP-1 on the process of glucose-stimulated insulin secretion. Diabetes (2002) 51:S434-42. doi: 10.2337/diabetes.51.2007.S434

5. Buteau J, Foisy S, Joly E, Prentki, M. Glucagon-like peptide 1 induces pancreatic $\beta$-cell proliferation via transactivation of the epidermal growth factor receptor. Diabetes (2003) 52:124-32. doi: 10.2337/diabetes.52.1.124

6. Nielsen LL, Young AA, Parkes DG. Pharmacology of exenatide (synthetic exendin-4): a potential therapeutic for improved glycemic control of type 2 diabetes. Regul Pept. (2004) 117:77-88. doi: 10.1016/j.regpep.2003.10.028

7. Park S, Dong X, Fisher TL, Dunn S, Omer AK, Weir G, et al. Exendin-4 uses Irs2 signaling to mediate pancreatic beta cell growth and function. J Biol Chem. (2006) 281:1159-68. doi: 10.1074/jbc.M508307200

8. Portha B, Tourrel-Cuzin C, Movassat J. Activation of the GLP-1 receptor signalling pathway: a relevant strategy to repair a deficient beta-cell mass. Exp Diabetes Res. (2011) 2011:376509. doi: 10.1155/2011/376509

9. Light PE, Manning Fox JE, Riedel MJ, Wheeler MB. Glucagon-like peptide1 inhibits pancreatic ATP-sensitive potassium channels via a protein kinase A- and ADP-dependent mechanism. Mol Endocrinol. (2002) 16:2135-44. doi: 10.1210/me.2002-0084

10. Larsen PJ, Tang-Christensen M, Holst JJ, Orskov C. Distribution of glucagon-like peptide-1 and other preproglucagon-derived peptides in the rat hypothalamus and brainstem. Neuroscience (1997) 77:257-70. doi: 10.1016/S0306-4522(96)00434-4

11. Traub S, Meier DT, Schulze F, Dror E, Nordmann TM, Goetz N, et al. Pancreatic $\alpha$ cell-derived glucagon-related peptides are required for $\beta$ cell adaptation and glucose homeostasis. Cell Rep. (2017) 18:3192-203. doi: 10.1016/j.celrep.2017.03.005

12. Piro S, Mascali LG, Urbano F, Filippello A, Malaguarnera R, Calanna $S$, et al. Chronic exposure to GLP-1 increases GLP-1 synthesis and release in a pancreatic alpha cell line $(\alpha-\mathrm{TC} 1)$ : evidence of a direct effect of GLP-1 on pancreatic alpha cells. PLoS ONE (2014) 9:e90093. doi: 10.1371/journal.pone.0090093 different aspects of GLP-1 biology with therapeutic potential not only for T2D and obesity, but also for heart, liver, kidney, lung and brain related disorders.

\section{AUTHOR CONTRIBUTIONS}

JR and RC conceived the idea, organized, and designed the manuscript. JR wrote the first draft, which was reviewed by RC, $\mathrm{JH}$, and PN. Figures were designed by JR and RC. All authors contributed in manuscript revision and agreed with the final submitted version.

\section{ACKNOWLEDGMENTS}

The authors thank the Curtin School of Pharmacy and Biomedical Sciences, and CHIRI, for research support and provision of excellent facilities.

13. Whalley NM, Pritchard LE, Smith DM, White A. Processing of proglucagon to GLP-1 in pancreatic alpha-cells: is this a paracrine mechanism enabling GLP-1 to act on beta-cells? J Endocrinol. (2011) 211:99-106. doi: 10.1530/JOE-11-0094

14. Holt MK, Trapp S. The physiological role of the brain GLP-1 system in stress. Cogent Biol. (2016) 2:1229086. doi: 10.1080/23312025.2016.1229086

15. Doyle ME, Egan JM. Mechanisms of Action of GLP-1 in the Pancreas. Pharmacol Ther. (2007) 113:546-93. doi: 10.1016/j.pharmthera.2006.11.007

16. Meloni AR, DeYoung MB, Lowe C, Parkes DG. GLP-1 receptor activated insulin secretion from pancreatic $\beta$-cells: mechanism and glucose dependence. Diabetes Obes Metab. (2013) 15:15-27. doi: 10.1111/j.1463-1326.2012.01663.x

17. Peyot ML, Gray JP, Lamontagne J, Smith PJ, Holz GG, Madiraju SR, et al. Glucagon-like peptide-1 induced signaling and insulin secretion do not drive fuel and energy metabolism in primary rodent pancreatic beta-cells. PLoS ONE (2009) 4:e6221. doi: 10.1371/journal.pone.0006221

18. Carlessi R, Chen Y, Rowlands J, Cruzat VF, Keane KN, Egan L, et al. GLP-1 receptor signalling promotes beta-cell glucose metabolism via mTOR-dependent HIF-1alpha activation. Sci Rep. (2017) 7:2661. doi: 10.1038/s41598-017-02838-2

19. Rowlands J, Cruzat V, Carlessi R, Newsholme P. Insulin and IGF-1 receptor autocrine loops are not required for Exendin-4 induced changes to pancreatic $\beta$-cell bioenergetic parameters and metabolism in BRIN-BD11 cells. Peptides (2018) 100:140-9. doi: 10.1016/j.peptides.2017.11.015

20. Cornu M, Modi H, Kawamori D, Kulkarni RN, Joffraud M, Thorens B. Glucagon-like peptide-1 increases beta-cell glucose competence and proliferation by translational induction of insulin-like growth factor-1 receptor expression. J Biol Chem. (2010) 285:10538-45. doi: 10.1074/jbc.M109.091116

21. S. Van de Velde, Hogan MF, Montminy M. mTOR links incretin signaling to HIF induction in pancreatic beta cells. Proc Natl Acad Sci USA. (2011) 108:16876-82. doi: 10.1073/pnas.1114228108

22. Drucker DJ, Dritselis A, Kirkpatrick P. Liraglutide. Nat Rev Drug Discov. (2010) 9:267-8. doi: 10.1038/nrd3148

23. Zheng X, Li Y, Fu G, Gong M. Application of novel peptide (Pp1) improving the half-life of exendin-4 in vivo. Peptides (2011) 32:964-70. doi: 10.1016/j.peptides.2011.02.009

24. Retnakaran R, Kramer CK, Choi H, Swaminathan B, Zinman B. Liraglutide and the preservation of pancreatic beta-cell function in early type 2 diabetes: the LIBRA trial. Diabetes Care (2014) 37:3270-8. doi: 10.2337/dc14-0893

25. Trujillo JM, Nuffer W, Ellis SL. GLP-1 receptor agonists: a review of head-to-head clinical studies. Ther Adv Endocrinol Metab. (2015) 6:19-28. doi: $10.1177 / 2042018814559725$ 
26. Athauda D, Foltynie T. The glucagon-like peptide 1 (GLP) receptor as a therapeutic target in Parkinson's disease: mechanisms of action. Drug Discovery Today (2016) 21:802-18. doi: 10.1016/j.drudis.2016. 01.013

27. Cantini G, Mannucci E, Luconi M. Perspectives in GLP-1 research: new targets, new receptors. Trends Endocrinol Metab. (2016) 27:427-38. doi: 10.1016/j.tem.2016.03.017

28. Godyn J, Jonczyk J, Panek D, Malawska B. Therapeutic strategies for Alzheimer's disease in clinical trials. Pharmacol Rep. (2016) 68:127-38. doi: 10.1016/j.pharep.2015.07.006

29. Goud A, Zhong J, Peters M, Brook RD, Rajagopalan S. GLP-1 agonists and blood pressure: a review of the evidence. Curr Hypertens Rep. (2016) 18:16. doi: 10.1007/s11906-015-0621-6

30. Katsurada K, Yada T. Neural effects of gut- and brain-derived glucagonlike peptide-1 and its receptor agonist. J Diabetes Investig. 7 (Suppl.) (2016) 1:64-9. doi: 10.1111/jdi.12464

31. Geloneze B, de Lima-Júnior JC, Velloso LA. Glucagon-like peptide-1 receptor agonists (GLP-1RAs) in the brain-adipocyte axis. Drugs (2017) 77:493-503. doi: 10.1007/s40265-017-0706-4

32. Henquin JC. Triggering and amplifying pathways of regulation of insulin secretion by glucose. Diabetes (2000) 49:1751-60. doi: 10.2337/diabetes.49.11.1751

33. Cohen $\mathrm{P}$. The twentieth century struggle to decipher insulin signalling. Nat Rev Mol Cell Biol. (2006) 7:867-73. doi: 10.1038/nrm2043

34. Gromada J, Brock B, Schmitz O, Rorsman P. Glucagonlike peptide-1: regulation of insulin secretion and therapeutic potential. Basic Clin Pharmacol Toxicol. (2004) 95:252-62. doi: 10.1111/j.1742-7843.2004.t01-1-pto950502.x

35. Saltiel AR, Kahn CR. Insulin signalling and the regulation of glucose and lipid metabolism. Nature (2001) 414:799-806. doi: 10.1038/414799a

36. Barg S, Huang P, Eliasson L, Nelson DJ, Obermuller S, Rorsman P, et al. Priming of insulin granules for exocytosis by granular $\mathrm{Cl}(-)$ uptake and acidification. J Cell Sci (2001) 114:2145-54.

37. Beguin $P$, Nagashima K, Nishimura $M$, Gonoi T, Seino S. PKAmediated phosphorylation of the human K(ATP) channel: separate roles of Kir6.2 and SUR1 subunit phosphorylation. EMBO J. (1999) 18:4722-32. doi: 10.1093/emboj/18.17.4722

38. Kang GX, Leech CA, Chepurny OG, Coetzee WA, Holz GG. Role of the cAMP sensor Epac as a determinant of K-ATP channel ATP sensitivity in human pancreatic beta-cells and rat INS-1 cells. J Phys Lond (2008) 586:1307-19. doi: 10.1113/jphysiol.2007.143818

39. Chitnis MM, Yuen JS, Protheroe AS, Pollak M, Macaulay VM. The type 1 insulin-like growth factor receptor pathway. Clin Cancer Res. (2008) 14:6364-70. doi: 10.1158/1078-0432.CCR-07-4879

40. Donnelly D. The structure and function of the glucagon-like peptide1 receptor and its ligands. $\mathrm{Br} J$ Pharmacol. (2012) 166:27-41. doi: 10.1111/j.1476-5381.2011.01687.x

41. Wang Y, Okamoto M, Schmitz F, Hofmann K, Sudhof TC. Rim is a putative Rab3 effector in regulating synaptic-vesicle fusion. Nature (1997) 388:593-8. doi: $10.1038 / 41580$

42. Fujimoto K, Shibasaki T, Yokoi N, Kashima Y, Matsumoto M, Sasaki T, et al. Piccolo, a Ca2 + sensor in pancreatic beta-cells. Involvement of cAMPGEFII. Rim2. Piccolo complex in cAMP-dependent exocytosis. J Biol Chem. (2002) 277:50497-502. doi: 10.1074/jbc.M210146200

43. Holz GG. Epac: a new cAMP-binding protein in support of glucagon-like peptide-1 receptor-mediated signal transduction in the pancreatic beta-cell. Diabetes (2004) 53:5-13. doi: 10.2337/diabetes.53.1.5

44. Kang G, Joseph JW, Chepurny OG, Monaco M, Wheeler MB, Bos JL, et al. Epac-selective cAMP analog 8-pCPT-2'-O-Me-cAMP as a stimulus for $\mathrm{Ca} 2+$-induced $\mathrm{Ca} 2+$ release and exocytosis in pancreatic beta-cells. J Biol Chem. (2003) 278:8279-85. doi: 10.1074/jbc.M211682200

45. Kang G, Holz GG. Amplification of exocytosis by $\mathrm{Ca} 2+$-induced $\mathrm{Ca} 2+$ release in INS-1 pancreatic $\beta$ cells. J Physiol. (2003) 546:175-89. doi: 10.1113/jphysiol.2002.029959

46. Tsuboi T, da Silva Xavier G, Holz GG, Jouaville LS, Thomas AP, Rutter GA. Glucagon-like peptide-1 mobilizes intracellular $\mathrm{Ca} 2+$ and stimulates mitochondrial ATP synthesis in pancreatic MIN6 beta-cells. Biochem J. (2003) 369:287-99. doi: 10.1042/bj20021288
47. Kang G, Chepurny OG, Rindler MJ, Collis L, Chepurny Z, Li WH, et al. A cAMP and $\mathrm{Ca} 2+$ coincidence detector in support of $\mathrm{Ca} 2+$-induced $\mathrm{Ca} 2+$ release in mouse pancreatic beta cells. J Physiol. (2005) 566:173-88. doi: 10.1113/jphysiol.2005.087510

48. Ding WG, Gromada J. Protein kinase A-dependent stimulation of exocytosis in mouse pancreatic $\beta$-cells by glucose-dependent insulinotropic polypeptide. Diabetes (1997) 46:615-21. doi: 10.2337/diab.46.4.615

49. Skelin M, Rupnik M. cAMP increases the sensitivity of exocytosis to $\mathrm{Ca}(2)+$ primarily through protein kinase $\mathrm{A}$ in mouse pancreatic beta cells. Cell Calcium (2011) 49:89-99. doi: 10.1016/j.ceca.2010.12.005

50. Gheni G, Ogura M, Iwasaki M, Yokoi N, Minami K, Nakayama Y, et al. Glutamate acts as a key signal linking glucose metabolism to Incretin/cAMP action to amplify insulin secretion. Cell Rep. (2014) 9:661-73. doi: 10.1016/j.celrep.2014.09.030

51. Jhala US, Canettieri G, Screaton RA, Kulkarni RN, Krajewski S, Reed J, et al. cAMP promotes pancreatic beta-cell survival via CREB-mediated induction of IRS2. Genes Dev. (2003) 17:1575-80. doi: 10.1101/gad.1097103

52. Wang Q, Brubaker P. Glucagon-like peptide-1 treatment delays the onset of diabetes in 8 week-old $\mathrm{db} / \mathrm{db}$ mice. Diabetologia (2002) 45:1263-73. doi: 10.1007/s00125-002-0828-3

53. Farilla L, Bulotta A, Hirshberg B, Li Calzi S, Khoury N, Noushmehr $\mathrm{H}$, et al. Glucagon-like peptide 1 inhibits cell apoptosis and improves glucose responsiveness of freshly isolated human islets. Endocrinology (2003) 144:5149-58. doi: 10.1210/en.2003-0323

54. Wang Q, Li L, Xu E, Wong V, Rhodes C, Brubaker P. Glucagon-like peptide-1 regulates proliferation and apoptosis via activation of protein kinase B in pancreatic INS-1 beta cells. Diabetologia (2004) 47:478-87. doi: 10.1007/s00125-004-1327-5

55. Miao XY, Gu ZY, Liu P, Hu Y, Li L, Gong YP, et al. The human glucagonlike peptide-1 analogue liraglutide regulates pancreatic beta-cell proliferation and apoptosis via an AMPK/mTOR/P70S6K signaling pathway. Peptides (2013) 39:71-9. doi: 10.1016/j.peptides.2012.10.006

56. Carlessi R, Lemos NE, Dias AL, Brondani LA, Oliveira JR, Bauer AC, et al. Exendin-4 attenuates brain death-induced liver damage in the rat. Liver Transpl. (2015) 21:1410-8. doi: 10.1002/lt.24317

57. Carlessi R, Lemos NE, Dias AL, Oliveira FS, Brondani LA, Canani $\mathrm{LH}$, et al. Exendin-4 protects rat islets against loss of viability and function induced by brain death. Mol Cell Endocrinol. (2015) 412:239-50. doi: 10.1016/j.mce.2015.05.009

58. Buteau J, El-Assaad W, Rhodes C, Rosenberg L, Joly E, Prentki M. Glucagonlike peptide-1 prevents beta cell glucolipotoxicity. Diabetologia (2004) 47:806-15. doi: 10.1007/s00125-004-1379-6

59. Tsunekawa S, Yamamoto N, Tsukamoto K, Itoh Y, Kaneko Y, Kimura T, et al. Protection of pancreatic $\beta$-cells by exendin- 4 may involve the reduction of endoplasmic reticulum stress; in vivo and in vitro studies. J Endocrinol. (2007) 193:65-74. doi: 10.1677/JOE-06-0148

60. Shimoda M, Kanda Y, Hamamoto S, Tawaramoto K, Hashiramoto M, Matsuki $\mathrm{M}$, et al. The human glucagon-like peptide-1 analogue liraglutide preserves pancreatic beta cells via regulation of cell kinetics and suppression of oxidative and endoplasmic reticulum stress in a mouse model of diabetes. Diabetologia (2011) 54:1098-108. doi: 10.1007/s00125-011-2069-9

61. Dalle S, Quoyer J, Varin E, Costes S. Roles and regulation of the transcription factor CREB in pancreatic beta -cells. Curr Mol Pharmacol. (2011) 4:187-95. doi: 10.2174/1874467211104030187

62. Vossler MR, Yao H, York RD, Pan MG, Rim CS, Stork PJS. cAMP Activates MAP Kinase and Elk-1 through a B-Raf- and Rap1-dependent pathway. Cell (1997) 89:73-82. doi: 10.1016/S0092-8674(00)80184-1

63. Stork PJS, Schmitt JM. Crosstalk between cAMP and MAP kinase signaling in the regulation of cell proliferation. Trends Cell Biol. (2002) 12:258-66. doi: 10.1016/S0962-8924(02)02294-8

64. Buteau J, Foisy S, Rhodes CJ, Carpenter L, Biden TJ, Prentki M. Protein Kinase CS activation mediates glucagon-like peptide-1induced pancreatic $\beta$-cell proliferation. Diabetes (2001) 50:2237-43. doi: 10.2337/diabetes.50.10.2237

65. Dai C, Hang Y, Shostak A, Poffenberger G, Hart N, Prasad N, et al. Age-dependent human $\beta$ cell proliferation induced by glucagon-like peptide 1 and calcineurin signaling. J Clin Investig. (2017) 127:3835-44. doi: $10.1172 /$ JCI91761 
66. Ellenbroek JH, Töns HA, Westerouen van Meeteren MJ, de Graaf N, Hanegraaf MA, Rabelink TJ, et al. Glucagon-like peptide-1 receptor agonist treatment reduces beta cell mass in normoglycaemic mice. Diabetologia (2013) 56:1980-6. doi: 10.1007/s00125-013-2957-2

67. Gedulin BR, Nikoulina SE, Smith PA, Gedulin G, Nielsen LL, Baron AD, et al. Exenatide (exendin-4) improves insulin sensitivity and \{beta\}-cell mass in insulin-resistant obese fa/fa Zucker rats independent of glycemia and body weight. Endocrinology (2005) 146:2069-76. doi: 10.1210/en.2004-1349

68. Sheikh-Ali M, Sultan S, Alamir AR, Haas MJ, Mooradian AD. Hyperglycemia-induced endoplasmic reticulum stress in endothelial cells. Nutrition (2010) 26:1146-50. doi: 10.1016/j.nut.2009.08.019

69. Newsholme P, Keane D, Welters HJ, Morgan NG. Life and death decisions of the pancreatic $\beta$-cell: the role of fatty acids. Clin Sci. (2007) 112:27-42. doi: 10.1042/CS20060115

70. Wrede CE, Dickson LM, Lingohr MK, Briaud I, Rhodes CJ. Protein kinase $\mathrm{B} /$ Akt prevents fatty acid-induced apoptosis in pancreatic beta-cells (INS-1). J Biol Chem. (2002) 277:49676-84. doi: 10.1074/jbc.M208756200

71. Fonseca SG, Gromada J, Urano F. Endoplasmic reticulum stress and pancreatic $\beta$-cell death. Trends Endocrinol Metab. (2011) 22:266-74. doi: 10.1016/j.tem.2011.02.008

72. Eizirik DL, Cardozo AK, Cnop M. The role for endoplasmic reticulum stress in diabetes mellitus. Endocr Rev. (2007) 29:42-61. doi: 10.1210/er.2007-0015

73. Xu C, Bailly-Maitre B, Reed JC. Endoplasmic reticulum stress: cell life and death decisions. J Clin Invest. (2005) 115:2656. doi: 10.1172/JCI26373

74. Yusta B, Baggio LL, Estall JL, Koehler JA, Holland DP, Li H, et al. GLP1 receptor activation improves $\beta$ cell function and survival following induction of endoplasmic reticulum stress. Cell Metab. (2006) 4:391-406. doi: 10.1016/j.cmet.2006.10.001

75. Scheuner D, Vander Mierde D, Song B, Flamez D, Creemers JW, Tsukamoto $\mathrm{K}$, et al. Control of mRNA translation preserves endoplasmic reticulum function in beta cells and maintains glucose homeostasis. Nat Med. (2005) 11:757. doi: $10.1038 / \mathrm{nm} 1259$

76. Harding HP, Zhang Y, Bertolotti A, Zeng H, Ron D. Perk is essential for translational regulation and cell survival during the unfolded protein response. Mol Cell (2000) 5:897-904. doi: 10.1016/S1097-2765(00)80330-5

77. McCullough KD, Martindale JL, Klotz OL, Aw TY, Holbrook NJ. Gadd153 sensitizes cells to endoplasmic reticulum stress by down-regulating Bcl2 and perturbing the cellular redox state. Mol Cell Biol. (2001) 21:1249-59. doi: 10.1128/MCB.21.4.1249-1259.2001

78. Cnop M, Ladriere L, Hekerman P, Ortis F, Cardozo AK, Dogusan Z, et al. Selective inhibition of eukaryotic translation initiation factor 2 alpha dephosphorylation potentiates fatty acid-induced endoplasmic reticulum stress and causes pancreatic beta-cell dysfunction and apoptosis. J Biol Chem. (2007) 282:3989-97. doi: 10.1074/jbc.M607627200

79. Oslowski CM, Urano F. The binary switch between life and death of endoplasmic reticulum-stressed beta cells. Curr Opin Endocrinol Diabetes Obes. (2010) 17:107-12. doi: 10.1097/MED.0b013e3283372843

80. Han D, Lerner AG, Walle LV, Upton JP, Xu W, Hagen A, et al. IRE1 $\alpha$ kinase activation modes control alternate endoribonuclease outputs to determine divergent cell fates. Cell (2009) 138:562-75. doi: 10.1016/j.cell.2009. 07.017

81. Eizirik DL, Miani M, Cardozo AK. Signalling danger: endoplasmic reticulum stress and the unfolded protein response in pancreatic islet inflammation. Diabetologia (2013) 56:234-41. doi: 10.1007/s00125-012-2762-3

82. Lenzen S. Oxidative stress: the Vulnerable $\beta$-cell. Biochem Soc Trans. (2008). 36(Pt 3):343-7. doi: 10.1042/BST0360343

83. Keane KN, Cruzat VF, Carlessi R, de Bittencourt PIH, Newsholme P. Molecular events linking oxidative stress and inflammation to insulin resistance and $\beta$-cell dysfunction. Oxid Med Cell Longev (2015) 2015:181643. doi: $10.1155 / 2015 / 181643$

84. Biden TJ, Boslem E, Chu KY, Sue N. Lipotoxic endoplasmic reticulum stress, $\beta$ cell failure, and type 2 diabetes mellitus. Trends Endocrinol Metab. (2014) 25:389-98. doi: 10.1016/j.tem.2014.02.003

85. Buteau J. GLP-1 receptor signaling: effects on pancreatic $\beta$-cell proliferation and survival. Diabetes Metab. (2008) 34 (Suppl.) 2:S73-7. doi: 10.1016/S1262-3636(08)73398-6

86. Cunha DA, Ladrière L, Ortis F, Igoillo-Esteve M, Gurzov EN, Lupi R, et al. Glucagon-like peptide-1 agonists protect pancreatic $\beta$-cells from lipotoxic endoplasmic reticulum stress through upregulation of $\mathrm{BiP}$ and JunB. Diabetes (2009) 58:2851-62. doi: 10.2337/db09-0685

87. Zummo FP, Cullen KS, Honkanen-Scott MJ, Shaw AM, Lovat PE, Arden C. Glucagon-Like Peptide 1 Protects Pancreatic $\beta$-Cells from death by increasing autophagic flux and restoring lysosomal function. Diabetes (2017) 66:1272-85. doi: 10.2337/db16-1009

88. Arden C. A role for glucagon-like peptide- 1 in the regulation of $\beta$-cell autophagy. Peptides (2018) 100:85-93. doi: 10.1016/j.peptides.2017.12.002

89. Codogno P, Mehrpour M, Proikas-Cezanne T. Canonical and non-canonical autophagy: variations on a common theme of self-eating? Nat Rev Mol Cell Biol. (2011) 13:7-12. doi: 10.1038/nrm3249

90. Levine B, Liu R, Dong X, Zhong Q. Beclin orthologs: integrative hubs of cell signaling, membrane trafficking, physiology. Trends Cell Biol. (2015) 25:533-44. doi: 10.1016/j.tcb.2015.05.004

91. Rogov V, Dotsch V, Johansen T, Kirkin V. Interactions between autophagy receptors and ubiquitin-like proteins form the molecular basis for selective autophagy. Mol Cell (2014) 53:167-78. doi: 10.1016/j.molcel.2013.12.014

92. Lamb CA, Yoshimori T, Tooze SA. The autophagosome: origins unknown, biogenesis complex. Nat Rev Mol Cell Biol. (2013) 14:759-74. doi: $10.1038 / \mathrm{nrm} 3696$

93. David Rubinsztein, C, Shpilka T, Elazar Z. Mechanisms of autophagosome biogenesis. Curr Biol. (2012) 22:R29-34. doi: 10.1016/j.cub.2011.11.034

94. Lim SW, Jin L, Jin J, Yang CW. Effect of exendin-4 on autophagy clearance in beta cell of rats with tacrolimus-induced diabetes mellitus. Sci Rep. (2016) 6:29921. doi: 10.1038/srep29921

95. Maiztegui B, Boggio V, Roman CL, Flores LE, Zotto HD, Ropolo A, et al. VMP1-related autophagy induced by a fructose-rich diet in beta-cells: its prevention by incretins. Clin Sci. (2017) 131:673-87. doi: 10.1042/CS20170010

96. Hall MN. mTOR-what does it do? Transpl Proc. (2008) 40:S5-8. doi: 10.1016/j.transproceed.2008.10.009

97. Duvel K, Yecies JL, Menon S, Raman P, Lipovsky AI, Souza AL, et al. Activation of a metabolic gene regulatory network downstream of mTOR complex 1. Mol Cell (2010) 39:171-83. doi: 10.1016/j.molcel.2010.06.022

98. Cornu M, Yang JY, Jaccard E, Poussin C, Widmann C, Thorens B. Glucagonlike peptide-1 protects beta-cells against apoptosis by increasing the activity of an Igf-2/Igf-1 receptor autocrine loop. Diabetes (2009) 58:1816-25. doi: $10.2337 / \mathrm{db} 09-0063$

99. Holz GG, Kühtreiber WM, Habener JF. Pancreatic beta-cells are rendered glucose-competent by the insulinotropic hormone glucagon-like peptide1(7-37). Nature (1993) 361:362-5. doi: 10.1038/361362a0

100. Holz GG, Leech CA, Heller RS, Castonguay M, Habener JF. cAMPdependent mobilization of intracellular $\mathrm{Ca} 2+$ stores by activation of ryanodine receptors in pancreatic beta-cells. A Ca2+ signaling system stimulated by the insulinotropic hormone glucagon-like peptide-1-(7-37). J Biol Chem. (1999) 274:14147-56. doi: 10.1074/jbc.274.20.14147

101. Bode HP, Moormann B, Dabew R, Göke B. Glucagon-like peptide 1 elevates cytosolic calcium in Pancreatic $\beta$-cells independently of protein kinase A1. Endocrinology (1999) 140:3919-27.

102. Leech CA, Dzhura I, Chepurny OG, Kang G, Schwede F, Genieser HG, et al. Molecular physiology of glucagon-like peptide-1 insulin secretagogue action in pancreatic $\beta$ cells. Prog Biophys Mol Biol. (2011) 107:236-47. doi: 10.1016/j.pbiomolbio.2011.07.005

103. Malhotra JD, Kaufman RJ. ER stress and its functional link to mitochondria: role in cell survival and death. Cold Spring Harb Perspect Biol. (2011) 3:a004424. doi: 10.1101/cshperspect.a004424

104. Senft D, Ze'ev, AR. UPR, autophagy, and mitochondria crosstalk underlies the ER stress response. Trends Biochem Sci. (2015) 40:141-8. doi: 10.1016/j.tibs.2015.01.002

105. Kuo IY, Ehrlich BE, Signaling in muscle contraction. Cold Spring Harb Pers Biol. (2015) 7:a006023. doi: 10.1101/cshperspect.a006023

106. Delgado E, Luque MA, Alcántara A, Trapote MA, Clemente F, Galera C, et al. Glucagon-like peptide-1 binding to rat skeletal muscle. Peptides (1995) 16:225-9. doi: 10.1016/0196-9781(94)00175-8

107. Alcántara AI, Morales M, Delgado E, López-Delgado I, Clemente F, Luque MA, et al. Exendin-4 agonist and Exendin(9-39)amide antagonist of the GLP-1(7-36)amide effects in liver and muscle. Arch Biochem Biophys. (1997) 341:1-7. doi: 10.1006/abbi.1997.9951 
108. Luque M, Gonzalez N, Marquez L, Acitores A, Redondo A, Morales M, et al. Glucagon-like peptide-1 (GLP-1) and glucose metabolism in human myocytes. J Endocrinol. (2002) 173:465-73. doi: 10.1677/joe.0.1730465

109. Green CJ, Henriksen TI, Pedersen BK, Solomon TP. Glucagon like peptide-1-induced glucose metabolism in differentiated human muscle satellite cells is attenuated by hyperglycemia. PLoS ONE (2012) 7:e44284. doi: 10.1371/journal.pone.0044284

110. Márquez L, Trapote MA, Luque MA, Valverde I, Villanueva-Pe-acarrillo ML. Inositolphosphoglycans possibly mediate the effects of glucagon-like peptide-1 (7-36) amide on rat liver and adipose tissue. Cell Biochem Funct. (1998) 16:51-6.

111. Yang H, Egan J, Wang Y, Moyes C, Roth J, Montrose M, et al. GLP-1 action in L6 myotubes is via a receptor different from the pancreatic GLP-1 receptor. Am J Physiol Cell Physiol. (1998) 275:C675-83. doi: 10.1152/ajpcell.1998.275.3.C675

112. Wei Y, Mojsov S. Tissue-specific expression of the human receptor for glucagon-like peptide-I: brain, heart and pancreatic forms have the same deduced amino acid sequences. FEBS Lett. (1995) 358:219-24. doi: 10.1016/0014-5793(94)01430-9

113. Whitaker GM, Lynn FC, McIntosh HS, Accili EA. Regulation of GIP and GLP1 receptor cell surface expression by N-glycosylation and receptor heteromerization. PLoS ONE (2012) 7:e32675. doi: 10.1371/journal.pone.0032675

114. Weston C, Poyner D, Patel V, Dowell S, Ladds G, Investigating G protein signalling bias at the glucagon-like peptide-1 receptor in yeast. $\mathrm{Br} J$ Pharmacol. (2014) 171:3651-65. doi: 10.1111/bph.12716

115. Pabreja K, Mohd MA, Koole C, Wootten D, Furness GB. review molecular mechanisms underlying physiological and receptor pleiotropic effects mediated by GLP-1R activation. Br J Pharmacol. (2014) 171:1114-28. doi: $10.1111 /$ bph.12313

116. Acitores A, Gonzalez N, Sancho V, Valverde I, Villanueva-Penacarrillo M. Cell signalling of glucagon-like peptide-1 action in rat skeletal muscle. $J$ Endocrinol. (2004) 180:389-98. doi: 10.1677/joe.0.1800389

117. González N, Acitores A, Sancho V, Valverde I, Villanueva-Pe-acarrillo ML. Effect of GLP-1 on glucose transport and its cell signalling in human myocytes. Regul Pept. (2005) 126:203-11. doi: 10.1016/j.regpep.2004.10.002

118. Arnés L, González N, Tornero-Esteban P, Sancho V, Acitores A, Valverde I, et al. Characteristics of GLP-1 and exendins action upon glucose transport and metabolism in type 2 diabetic rat skeletal muscle. Int J Mol Med. (2008) 22:127-32. doi: 10.3892/ijmm.22.1.127

119. Villanueva-Pe-acarrillo ML, Martín-Duce A, Ramos-Álvarez I, GutiérrezRojas I, Moreno P, Nuche-Berenguer B, et al. Characteristic of GLP-1 effects on glucose metabolism in human skeletal muscle from obese patients. Regul Pept. (2011) 168:39-44. doi: 10.1016/j.regpep.2011.03.002

120. Baggio LL, Ussher JR, McLean BA, Cao X, Kabir MG, Mulvihill EE, et al. The autonomic nervous system and cardiac GLP-1 receptors control heart rate in mice. Mol Metab. (2017) 6:1339-49. doi: 10.1016/j.molmet.2017.08.010

121. Li Z, Ni CL, Yao Z, Chen LM, Niu WY. Liraglutide enhances glucose transporter 4 translocation via regulation of AMP-activated protein kinase signaling pathways in mouse skeletal muscle cells. Metab Clin Exp. (2014) 63:1022-30. doi: 10.1016/j.metabol.2014.05.008

122. Andreozzi F, Raciti GA, Nigro C, Mannino GC, Procopio T, Davalli AM, et al. The GLP-1 receptor agonists exenatide and liraglutide activate Glucose transport by an AMPK-dependent mechanism. J Transl Med. (2016) 14:229. doi: 10.1186/s12967-016-0985-7

123. Decara J, Rivera P, Arrabal S, Vargas A, Serrano A, Pavón FJ, et al. Cooperative role of the glucagon-like peptide- 1 receptor and $\beta 3$-adrenergicmediated signalling on fat mass reduction through the downregulation of PKA/AKT/AMPK signalling in the adipose tissue and muscle of rats. Acta Physiol. (2017). 222:e13008. doi: 10.1111/apha.13008

124. Taylor EB, An D, Kramer HF, Yu H, Fujii NL, Roeckl KS, et al. Discovery of TBC1D1 as an insulin-, AICAR-, and contraction-stimulated signaling nexus in mouse skeletal muscle. J Biol Chem. (2008) 283:9787-96. doi: 10.1074/jbc.M708839200

125. Wong ST, Athos J, Figueroa XA, Pineda VV, Schaefer ML, Chavkin CC, et al. Calcium-stimulated adenylyl cyclase activity is critical for hippocampusdependent long-term memory and late phase LTP. Neuron (1999) 23:787-98. doi: 10.1016/S0896-6273(01)80036-2
126. Caldwell KK, Boyajian CLD, Cooper MF. The effects of $\mathrm{Ca} 2+$ and calmodulin on adenylyl cyclase activity in plasma membranes derived from neural and non-neural cells. Cell Calc. (1992) 13:107-21. doi: 10.1016/0143-4160(92)90004-C

127. Jaiswal BS, Conti M. Calcium regulation of the soluble adenylyl cyclase expressed in mammalian spermatozoa. Proc Natl Acad Sci USA. (2003) 100:10676-81. doi: 10.1073/pnas. 1831008100

128. Dunn TA, Storm DR, Feller MB. Calcium-dependent increases in protein kinase-a activity in mouse retinal ganglion cells are mediated by multiple adenylate cyclases. PLoS ONE (2009) 4:e7877. doi: 10.1371/journal.pone.0007877

129. Chai W, Dong Z, Wang N, Wang W, Tao L, Cao W, et al. Glucagonlike peptide 1 recruits microvasculature and increases glucose use in muscle via a nitric oxide-dependent mechanism. Diabetes (2012) 61:888-96. doi: $10.2337 / \mathrm{db} 11-1073$

130. Subaran SC, Sauder MA, Chai W, Jahn LA, Fowler DE, Aylor KW, et al. GLP-1 at physiological concentrations recruits skeletal and cardiac muscle microvasculature in healthy humans. Clin Sci. (2014) 127:163-70. doi: 10.1042/CS20130708

131. Nystrom T, Gutniak MK, Zhang Q, Zhang F, Holst JJ, Ahren B, et al. Effects of glucagon-like peptide-1 on endothelial function in type 2 diabetes patients with stable coronary artery disease. Am J Physiol Endocrinol Metab. (2004) 287:E1209-15. doi: 10.1152/ajpendo.00237.2004

132. Nystrom T. The potential beneficial role of glucagon-like peptide- 1 in endothelial dysfunction and heart failure associated with insulin resistance. Horm Metab Res. (2008) 40:593-606. doi: 10.1055/s-0028-1082326

133. Schisano B, Harte AL, Lois K, Saravanan P, Al-Daghri N, Al-Attas O, et al. GLP-1 analogue, Liraglutide protects human umbilical vein endothelial cells against high glucose induced endoplasmic reticulum stress. Regulatory Peptides (2012) 174:46-52. doi: 10.1016/j.regpep.2011.11.008

134. Morales PE, Torres G, Sotomayor-Flores C, Pena-Oyarzun D, RiveraMejias P, Paredes F, et al. GLP-1 promotes mitochondrial metabolism in vascular smooth muscle cells by enhancing endoplasmic reticulummitochondria coupling. Biochem Biophys Res Commun. (2014) 446:410-6. doi: 10.1016/j.bbrc.2014.03.004

135. Barragán JM, Eng J, Rodríguez R, Blázquez E. Neural contribution to the effect of glucagon-like peptide-1-(7-36) amide on arterial blood pressure in rats. Am J Physiol. (1999) 277:E784-91. doi: 10.1152/ajpendo.1999.277.5.E784

136. Edwards MB, Ghatei MA, Bloom SR. Subcutaneous glucagon-like peptide-1 (7-36) amide is insulinotropic and can cause hypoglycaemia in fasted healthy subjects. Clin Sci. (1998) 95:719-24. doi: 10.1042/cs0950719

137. Davidson MH. Cardiovascular effects of glucagonlike peptide-1 agonists. Am J Cardiol. (2011) 108:33B-41B. doi: 10.1016/j.amjcard.2011.03.046

138. Robinson LE, Holt TA, Rees K, Randeva HS, O’Hare JP. Effects of exenatide and liraglutide on heart rate, blood pressure and body weight: systematic review and meta-analysis. BMJ Open (2013) 3:e001986. doi: 10.1136/bmjopen-2012-001986

139. Noyan-Ashraf MH, Momen MA, Ban K, Sadi AM, Zhou YQ, Riazi AM, et al. GLP-1R agonist liraglutide activates cytoprotective pathways and improves outcomes after experimental myocardial infarction in mice. Diabetes (2009) 58:975-83. doi: 10.2337/db08-1193

140. May AT, Wang H, Mahavadi S, Grider JR, Murthy KS. Identification of expression and function of the glucagon-like peptide-1 receptor in gastrointestinal smooth muscle. FASEB J. (2017) 31:888.5.

141. Richard JE, Anderberg RH, Goteson A, Gribble FM, Reimann F, Skibicka KP. Activation of the GLP-1 receptors in the nucleus of the solitary tract reduces food reward behavior and targets the mesolimbic system. PLOS ONE (2015) 10:e0119034. doi: 10.1371/journal.pone.0119034

142. Challa TD, Beaton N, Arnold M, Rudofsky G, Langhans W, Wolfrum C. Regulation of adipocyte formation by GLP-1/GLP-1R signaling. J Biol Chem. (2012) 287:6421-30. doi: 10.1074/jbc.M111.310342

143. Meier JJ. GLP-1 receptor agonists for individualized treatment of type 2 diabetes mellitus. Nat Rev Endocrinol. (2012) 8:728. doi: 10.1038/nrendo.2012.140

144. Marathe CS, Rayner CK, Jones KL, Horowitz M. Effects of GLP-1 and incretin-based therapies on gastrointestinal motor function. Exp Diabetes Res. (2011). 2011:279530. doi: 10.1155/2011/279530 
145. Smits MM, Tonneijck L, Muskiet MH, Kramer M, Cahen D, van Raalte DH. Gastrointestinal actions of glucagon-like peptide-1-based therapies: glycaemic control beyond the pancreas. Diabetes Obes Metab. (2016) 18:22435. doi: 10.1111/dom.12593

146. Tolessa T, Gutniak M, Holst JJ, Efendic S, Hellström PM. Inhibitory effect of glucagon-like peptide-1 on small bowel motility. Fasting but not fed motility inhibited via nitric oxide independently of insulin and somatostatin. J Clin Investig. (1998) 102:764-74. doi: 10.1172/JCI942

147. Nauck MA, Niedereichholz U, Ettler R, Holst JJ, Ørskov C, Ritzel R, et al. Glucagon-like peptide 1 inhibition of gastric emptying outweighs its insulinotropic effects in healthy humans. Am J Physiol. (1997) 273:E981-8. doi: 10.1152/ajpendo.1997.273.5.E981

148. Näslund E, Gutniak M, Skogar S, Rössner S, Hellström PM. Glucagonlike peptide 1 increases the period of postprandial satiety and slows gastric emptying in obese men. Am J Clin Nutr. (1998) 68:525-30. doi: 10.1093/ajcn/68.3.525

149. Meier JJ, Gallwitz B, Salmen S, Goetze O, Holst JJ, Schmidt WE, et al. Normalization of glucose concentrations and deceleration of gastric emptying after solid meals during intravenous glucagon-like peptide 1 in patients with type 2 diabetes. J Clin Endocrinol Metab. (2003) 88:2719-25. doi: 10.1210/jc.2003-030049

150. Deane AM, Chapman MJ, Fraser RJ, Summers MJ, Zaknic AV, Storey JP, et al. Effects of exogenous glucagon-like peptide-1 on gastric emptying and glucose absorption in the critically ill: relationship to glycemia. Crit Care Med. (2010) 38:1261-9. doi: 10.1097/CCM.0b013e3181d9d87a

151. Delgado-Aros S, Kim DY, Burton DD, Thomforde GM, Stephens D, Brinkmann $\mathrm{BH}$, et al. Effect of GLP-1 on gastric volume, emptying, maximum volume ingested, and postprandial symptoms in humans. Am J Physiol. (2002) 282:G424-31. doi: 10.1152/ajpgi.2002.282.3.G424

152. Delgado-Aros S, Vella A, Camilleri M, Low PA, Burton D, Thomforde G, et al. Effects of glucagon-like peptide-1 and feeding on gastric volumes in diabetes mellitus with cardio-vagal dysfunction. Neurogastroenterol Motil. (2003) 15:435-43. doi: 10.1046/j.1365-2982.2003.00422.x

153. Schirra J, Nicolaus M, Woerle H, Struckmeier C, Katschinski M, Göke B. GLP-1 regulates gastroduodenal motility involving cholinergic pathways. Neurogastroenterol Motil (2009) 21:609. doi: 10.1111/j.1365-2982.2008.01246.x

154. Amato A, Baldassano S, Liotta R, Serio R, Mule F. Exogenous glucagon-like peptide 1 reduces contractions in human colon circular muscle. J Endocrinol. (2014) 221:29-37. doi: 10.1530/JOE-13-0525

155. Skov J. Effects of GLP-1 in the kidney. Rev Endo Metab Disord. (2014) 15:197-207. doi: 10.1007/s11154-014-9287-7

156. Thomson SC, Vallon V. Renal effects of incretin-based diabetes therapies: pre-clinical predictions and clinical trial outcomes. Curr Diabetes Rep. (2018) 18:28. doi: 10.1007/s11892-018-0991-7

157. Thomas MC. The potential and pitfalls of GLP-1 receptor agonists for renal protection in type 2 diabetes. Diabetes Metab. (2017) 43:2S20-7. doi: 10.1016/S1262-3636(17)30069-1

158. Katagiri D, Hamasaki Y, Doi K, Okamoto K, Negishi K, Nangaku M, et al. Protection of glucagon-like peptide-1 in cisplatin-induced renal injury elucidates gut-kidney connection. J Am Soc Nephrol. (2013) 24:2034-43. doi: 10.1681/ASN.2013020134

159. Muskiet MHA, Tonneijck L, Smits MM, van Baar MJB, Kramer $\mathrm{MHH}$, Hoorn EJ, et al. GLP-1 and the kidney: from physiology to pharmacology and outcomes in diabetes. Nat Rev. (2017) 13:605-28. doi: 10.1038/nrneph.2017.123

160. Yang H, Li H, Wang Z, Shi Y, Jiang G, Zeng F. Exendin-4 ameliorates renal ischemia-reperfusion injury in the rat. J Surg Res. (2013) 185:825-32. doi: 10.1016/j.jss.2013.06.042

161. Glastras SJ, Chen H, McGrath RT, Zaky AA, Gill AJ, Pollock CA, et al. Effect of GLP-1 receptor activation on offspring kidney health in a rat model of maternal obesity. Sci Rep. (2016) 6:23525. doi: 10.1038/srep23525

162. Dieter BP, Alicic RZ, Tuttle KR. GLP-1 Receptor agonists in diabetic kidney disease: from the patient-side to the bench-side. Am. J. Physiol. Renal. Physiol. (2018). doi: 10.1152/ajprenal.00211.2018. [Epub ahead of print].

163. Skov J, Holst JJ, Gøtze JP, Frøkiær J, Christiansen JS. Glucagon-like peptide1: effect on pro-atrial natriuretic peptide in healthy males. Endo Connect. (2014) 3:11-6. doi: 10.1530/EC-13-0087
164. Jensen EP, Poulsens SS, Kissow H, Holstein-Rathlou NH, Deacon CF, Jensen BL, et al. Activation of GLP-1 receptors on vascular smooth muscle cells reduces the autoregulatory response in afferent arterioles and increases renal blood flow. Am J Physiol Renal Physiol. (2015) 308:F867-77. doi: 10.1152/ajprenal.00527.2014

165. Farah LX, Valentini V, Pessoa TD, Malnic G, McDonough AA, Girardi AC. The physiological role of glucagon-like peptide-1 in the regulation of renal function. Am J Physiol Renal Physiol. (2015) 310:F123-7. doi: 10.1152/ajprenal.00394.2015

166. Fujita H, Morii T, Fujishima H, Sato T, Shimizu T, Hosoba M, et al. The protective roles of GLP-1R signaling in diabetic nephropathy: possible mechanism and therapeutic potential. Kidney Int. (2014) 85:579-89. doi: 10.1038/ki.2013.427

167. Skov J, Dejgaard A, Frøkiær J, Holst JJ, Jonassen T, Rittig S, et al. Glucagon-like peptide-1 (GLP-1): effect on kidney hemodynamics and renin-angiotensin-aldosterone system in healthy men. J Clin Endocrinol Metab. (2013) 98:E664-71. doi: 10.1210/jc.2012-3855

168. Pyke C, Heller RS, Kirk RK, Ørskov C, Reedtz-Runge S, Kaastrup P, et al. GLP-1 receptor localization in monkey and human tissue: novel distribution revealed with extensively validated monoclonal antibody. Endocrinology (2014) 155:1280-90. doi: 10.1210/en.2013-1934

169. Crajoinas RO, Oricchio FT, Pessoa TD, Pacheco BP, Lessa LM, Malnic G, et al. Mechanisms mediating the diuretic and natriuretic actions of the incretin hormone glucagon-like peptide-1. Am J Physiol Renal Physiol. (2011) 301:F355-63. doi: 10.1152/ajprenal.00729.2010

170. Moreno C, Mistry M, Roman RJ. Renal effects of glucagonlike peptide in rats. Eur J Pharmacol. (2002) 434:163-7. doi: 10.1016/S0014-2999(01)01542-4

171. Hirata K, Kume S, Araki S-I, Sakaguchi M, Chin-Kanasaki M, Isshiki $\mathrm{K}$, et al. Exendin-4 has an anti-hypertensive effect in saltsensitive mice model. Biochem Biophys Res Commun. (2009) 380:44-9. doi: 10.1016/j.bbrc.2009.01.003

172. Ishibashi Y, Matsui T, Ojima A, Nishino Y, Nakashima S, Maeda S, et al. Glucagon-like peptide-1 inhibits angiotensin II-induced mesangial cell damage via protein kinase A. Microvasc Res. (2012) 84:395-8. doi: 10.1016/j.mvr.2012.06.008

173. Kim M, Platt MJ, Shibasaki T, Quaggin SE, Backx PH, Seino S, et al. GLP1 receptor activation and Epac2 link atrial natriuretic peptide secretion to control of blood pressure. Nat Med. (2013) 19:567. doi: 10.1038/ nm.3128

174. Rieg T, Gerasimova M, Murray F, Masuda T, Tang T, Rose M, et al. Natriuretic effect by exendin-4, but not the DPP-4 inhibitor alogliptin, is mediated via the GLP-1 receptor and preserved in obese type 2 diabetic mice. Am J Physiol Renal Physiol. (2012) 303:F963-71. doi: 10.1152/ajprenal.00259.2012

175. Thomson SC, Kashkouli A, Singh P., Glucagon-like peptide-1 receptor stimulation increases GFR and suppresses proximal reabsorption in the rat. American journal of physiology. Renal physiol. (2013) 304:F137-44. doi: 10.1152/ajprenal.00064.2012

176. Muskiet M, Tonneijck L, Smits M, Kramer M, Diamant M, Joles J, et al. Acute renal haemodynamic effects of glucagon-like peptide-1 receptor agonist exenatide in healthy overweight men. Diabet Obes Metab. (2016) 18:178-85. doi: 10.1111/dom.12601

177. Li Y-K, Ma D-X, Wang Z-M, Hu X-F, Li S-L, Tian H-Z, et al. The glucagonlike peptide-1 (GLP-1) analog liraglutide attenuates renal fibrosis. Pharmacol Res. (2018) 131:102-11. doi: 10.1016/j.phrs.2018.03.004

178. Chen YT, Tsai TH, Yang CC, Sun CK, Chang LT, Chen HH, et al. Exendin4 and sitagliptin protect kidney from ischemia-reperfusion injury through suppressing oxidative stress and inflammatory reaction. J Transl Med. (2013) 11:270. doi: 10.1186/1479-5876-11-270

179. Mundil D, Cameron-Vendrig A, Husain M. GLP-1 receptor agonists: a clinical perspective on cardiovascular effects. Diabet Vasc Dis Res. (2012) 9:95-108. doi: 10.1177/1479164112441526

180. Panjwani N, Mulvihill EE, Longuet C, Yusta B, Campbell JE, Brown TJ, et al. GLP-1 receptor activation indirectly reduces hepatic lipid accumulation but does not attenuate development of atherosclerosis in diabetic male $\mathrm{ApoE}^{-/-}$ mice. Endocrinology (2013) 154:127-39. doi: 10.1210/en.2012-1937

181. Beiroa D, Imbernon M, Gallego R, Senra A, Herranz D, Villarroya F, et al. GLP-1 agonism stimulates brown adipose tissue thermogenesis 
and browning through hypothalamic AMPK. Diabetes (2014) 63:3346-58. doi: $10.2337 / \mathrm{db} 14-0302$

182. Kooijman S, Wang Y, Parlevliet ET, Boon MR, Edelschaap D, Snaterse G, et al. Central GLP-1 receptor signalling accelerates plasma clearance of triacylglycerol and glucose by activating brown adipose tissue in mice. Diabetologia (2015) 58:2637-46. doi: 10.1007/s00125-015-3727-0

183. Lockie SH, Heppner KM, Chaudhary N, Chabenne JR, Morgan DA, VeyratDurebex C, et al. Direct control of brown adipose tissue thermogenesis by central nervous system glucagon-like peptide-1 receptor signaling. Diabetes (2012) 61:2753-62. doi: 10.2337/db11-1556

184. Li X, Jiang L, Yang M, Wu Y, Sun S, Sun J. GLP-1 receptor agonist increases the expression of CTRP3, a novel adipokine, in 3T3-L1 adipocytes through PKA signal pathway. J Endocrinol Invest. (2015) 38:73-9. doi: 10.1007/s40618-014-0156-8

185. Chen JC, Zhao HC, Ma XL, Zhang YC, Lu SM, Wang YG, et al. GLP-1/GLP$1 \mathrm{R}$ signaling in regulation of adipocyte differentiation and lipogenesis. Cell Physiol Biochem. (2017) 42:1165-76. doi: 10.1159/000478872

186. Vendrell J, El Bekay R, Peral B, Garcia-Fuentes E, Megia A, MaciasGonzalez $\mathrm{M}$, et al. Study of the potential association of adipose tissue GLP-1 receptor with obesity and insulin resistance. Endocrinology (2011) 152:4072-9. doi: 10.1210/en.2011-1070

187. Lynch L, Hogan AE, Duquette D, Lester C, Banks A, LeClair K, et al. iNKT cells induce FGF21 for thermogenesis and are required for maximal weight loss in GLP1 therapy. Cell Metab. (2016) 24:510-9. doi: 10.1016/j.cmet.2016.08.003

188. Rudovich N, Pivovarova O, Gögebakan Ö, Sparwasser A, Doehner W, Anker SD, et al. Effect of exogenous intravenous administrations of GLP1 and/or GIP on circulating pro-atrial natriuretic peptide in subjects with different stages of glucose tolerance. Diabetes Care (2015) 38:e7-8. doi: $10.2337 / \mathrm{dc} 14-1452$

189. Mells JE, Fu PP, Sharma S, Olson D, Cheng L, Handy JA, et al. Glp-1 analog, liraglutide, ameliorates hepatic steatosis and cardiac hypertrophy in C57BL/6J mice fed a Western diet. Am J Physiol Gastrointest Liver Physiol. (2012) 302:G225-35. doi: 10.1152/ajpgi.00274.2011

190. Ussher JR, Baggio LL, Campbell JE, Mulvihill EE, Kim M, Kabir MG, et al. Inactivation of the cardiomyocyte glucagon-like peptide-1 receptor (GLP-1R) unmasks cardiomyocyte-independent GLP-1R-mediated cardioprotection. Mol Metab. (2014) 3:507-17. doi: 10.1016/j.molmet.2014.04.009

191. Ban K, Kim K-H, Cho C-K, Sauve M, Diamandis EP, Backx PH, et al. Glucagon-like peptide (GLP)-1 (9-36) amide-mediated cytoprotection is blocked by exendin (9-39) yet does not require the known GLP-1 receptor. Endocrinology (2010) 151:1520-31. doi: 10.1210/en.2009-1197

192. Ban K, Noyan-Ashraf MH, Hoefer J, Bolz S-S, Drucker DJ, Husain M. Cardioprotective and vasodilatory actions of glucagon-like peptide 1 receptor are mediated through both glucagon-like peptide 1 receptordependent and-independent pathways. Circulation (2008) 117:2340-50. doi: 10.1161/CIRCULATIONAHA.107.739938

193. Giblett JP, Clarke SJ, Dutka DP, Hoole SP. Glucagon-like peptide-1: a promising agent for cardioprotection during myocardial ischemia. JACC (2016) 1:267-76. doi: 10.1016/j.jacbts.2016.03.011

194. Green BD, Hand KV, Dougan JE, McDonnell BM, Cassidy RS, Grieve DJ. GLP-1 and related peptides cause concentration-dependent relaxation of rat aorta through a pathway involving KATP and cAMP. Arch Biochem Biophys. (2008) 478:136-42. doi: 10.1016/j.abb.2008.08.001

195. Noyan-Ashraf MH, Shikatani EA, Schuiki I, Mukovozov I, Wu J, Li R-K, et al. A glucagon-like peptide-1 analogue reverses the molecular pathology and cardiac dysfunction of a mouse model of obesity. Circulation (2012) 127:74-85. doi: 10.1161/CIRCULATIONAHA.112.091215

196. Tsai EJ, Kass DA. Cyclic GMP signaling in cardiovascular pathophysiology and therapeutics. Pharmacol Therap. (2009) 122:216-38. doi: 10.1016/j.pharmthera.2009.02.009

197. Nikolaidis LA, Doverspike A, Hentosz T, Zourelias L, Shen Y-T, Elahi D, et al. Glucagon-like peptide-1 limits myocardial stunning following brief coronary occlusion and reperfusion in conscious canines. J Pharmacol Exp Therap. (2005) 312:303-8. doi: 10.1124/jpet.104.073890

198. Nikolaidis LA, Elahi D, Hentosz T, Doverspike A, Huerbin R, Zourelias $\mathrm{L}$, et al. Recombinant glucagon-like peptide-1 increases myocardial glucose uptake and improves left ventricular performance in conscious dogs with pacing-induced dilated cardiomyopathy. Circulation (2004) 110:955-61. doi: 10.1161/01.CIR.0000139339.85840.DD

199. Hausenloy DJ, Tsang A, Yellon DM. The reperfusion injury salvage kinase pathway: a common target for both ischemic preconditioning and postconditioning. Trends Cardiovasc Med. (2005) 15:69-75. doi: 10.1016/j.tcm.2005.03.001

200. Ravassa S, Zudaire A, Díez J. GLP-1 and cardioprotection: from bench to bedside. Cardiovasc Res. (2012) 94:316-23. doi: 10.1093/cvr/cvs123

201. Timmers L, Henriques JP, de Kleijn DP, DeVries JH, Kemperman H, Steendijk P, et al. Exenatide reduces infarct size and improves cardiac function in a porcine model of ischemia and reperfusion injury. J Am Coll Cardiol. (2009) 53:501-10. doi: 10.1016/j.jacc.2008.10.033

202. Kristiansen SB, Henning O, Kharbanda RK, Nielsen-Kudsk JE, Schmidt MR, Redington AN, et al. Remote preconditioning reduces ischemic injury in the explanted heart by a KATP channel-dependent mechanism. Am J Physiol Heart Circ Physiol. (2005) 288:H1252-6. doi: 10.1152/ajpheart.00207.2004

203. Garlid KD, Paucek P, Yarov-Yarovoy V, Murray HN, Darbenzio $\mathrm{RB}$, D’Alonzo AJ, et al. Cardioprotective effect of diazoxide and its interaction with mitochondrial ATP-sensitive $\mathrm{K}+$ channels: possible mechanism of cardioprotection. Circ Res. (1997) 81:1072-82. doi: 10.1161/01.RES.81.6.1072

204. Krieg T, Qin Q, McIntosh EC, Cohen MV, Downey JM. ACh and adenosine activate PI3-kinase in rabbit hearts through transactivation of receptor tyrosine kinases. Am J Physiol Heart Circ Physiol. (2002) 283:H2322-30. doi: 10.1152/ajpheart.00474.2002

205. Cohen MV, Baines CP, Downey JM. Ischemic preconditioning: from adenosine receptor to KATP channel. Annu Rev Physiol. (2000) 62:79-109. doi: 10.1146/annurev.physiol.62.1.79

206. Nikolaidis LA, Mankad S, Sokos GG, Miske G, Shah A, Elahi D, et al. Effects of glucagon-like peptide-1 in patients with acute myocardial infarction and left ventricular dysfunction after successful reperfusion. Circulation (2004) 109:962-5. doi: 10.1161/01.CIR.0000120505.91348.58

207. Sokos GG, Nikolaidis LA, Mankad S, Elahi D, Shannon RP. Glucagon-like peptide-1 infusion improves left ventricular ejection fraction and functional status in patients with chronic heart failure. J. cardiac failure (2006) 12:694699. doi: 10.1016/j.cardfail.2006.08.211

208. Sokos GG, Bolukoglu H, German J, Hentosz T, Magovern GJ, Maher TD, et al. Effect of glucagon-like peptide-1 (GLP-1) on glycemic control and left ventricular function in patients undergoing coronary artery bypass grafting. Am J Cardiol. (2007) 100:824-9. doi: 10.1016/j.amjcard.2007.05.022

209. McCormick LM, Hoole SP, White PA, Read PA, Axell RG, Clarke SJ, et al. Pre-treatment with glucagon-like peptide-1 protects against ischemic left ventricular dysfunction and stunning without a detected difference in myocardial substrate utilization. JACC Cardiovasc Interv. (2015) 8:292-301. doi: 10.1016/j.jcin.2014.09.014

210. Kohl BA, Hammond MS, Cucchiara AJ, Ochroch EA. Intravenous GLP1 (7-36) amide for prevention of hyperglycemia during cardiac surgery: a randomized, double-blind, placebo-controlled study. J Cardiothorac Vasc Anesth. (2014) 28:618-25. doi: 10.1053/j.jvca.2013.06.021

211. Woo JS, Kim W, Ha SJ, Kim JB, Kim S-J, Kim W-S, et al. Cardioprotective effects of exenatide in patients with ST-segment-elevation myocardial infarction undergoing primary percutaneous coronary interventionsignificance: results of exenatide myocardial protection in revascularization study. Arterioscler Thromb Vasc Biol. (2013) 33:2252-60. doi: 10.1161/ATVBAHA.113.301586

212. Hoole SP, White PA, Khan FZ, O'Sullivan M, West NE, Dutka DP. A pilot study to assess whether glucagon-like peptide-1 protects the heart from ischemic dysfunction and attenuates stunning after coronary balloon occlusion in humans clinical perspective. Circ Cardiovasc Interv. (2011) 4:266-72. doi: 10.1161/CIRCINTERVENTIONS.110.960476

213. Lønborg J, Vejlstrup N, Kelbæk H, Bøtker HE, Kim WY, Mathiasen $A B$, et al. Exenatide reduces reperfusion injury in patients with STsegment elevation myocardial infarction. Eur Heart J. (2012) 33:1491-9. doi: 10.1093/eurheartj/ehr309

214. Marso SP, Bain SC, Consoli A, Eliaschewitz FG, Jodar E, Leiter LA, et al. Investigators, semaglutide and cardiovascular outcomes in patients with type 2 diabetes. N Engl J Med. (2016) 375:1834-44. doi: 10.1056/NEJMoa1607141 
215. Marso SP, Daniels GH, Brown-Frandsen K, Kristensen P, Mann JF, Nauck MA, et al. Liraglutide and cardiovascular outcomes in type 2 diabetes. N Engl J Med. (2016) 375:311-22. doi: 10.1056/NEJMoa1603827

216. D'alessio D, Vahl T, Prigeon R., Effects of glucagon-like peptide 1 on the hepatic glucose metabolism. Horm Metab Res. (2004) 36:837-41. doi: $10.1055 / \mathrm{s}-2004-826172$

217. Larsson H, Holst JJ, Ahren B. Glucagon-like peptide-1 reduces hepatic glucose production indirectly through insulin and glucagon in humans. Acta Physiol Scand. (1997) 160:413-22. doi: 10.1046/j.1365-201X.1997.00161.x

218. Redondo A, Trigo M, Acitores A, Valverde I, Villanueva-Pe-acarrillo MAL. Cell signalling of the GLP-1 action in rat liver. Mol Cell Endocrinol. (2003) 204:43-50. doi: 10.1016/S0303-7207(03)00146-1

219. Ikezawa $Y$, Yamatani K, Ohnuma H, Daimon M, Manaka H, Sasaki H. Glucagon-like peptide-1 inhibits glucagon-induced glycogenolysis in perivenous hepatocytes specifically. Regulat Peptides (2003) 111:207-10. doi: 10.1016/S0167-0115(02)00287-2

220. Gupta NA, Mells J, Dunham RM, Grakoui A, Handy J, Saxena NK, et al. Glucagon-like peptide-1 receptor (GLP-1R) is present on human hepatocytes and has a direct role in decreasing hepatic steatosis in vitro by modulating elements of the insulin signaling pathway. Hepatology (2010) 51:1584-92. doi: 10.1002/hep. 23569

221. Aviv V, Meivar-Levy I, Rachmut IH, Rubinek T, Mor E, Ferber S. Exendin4 promotes liver cell proliferation and enhances the PDX-1-induced liver to pancreas transdifferentiation process. J Biol Chem. (2009) 284:33509-20. doi: 10.1074/jbc.M109.017608

222. Bullock BP, Heller RS, Habener JF. Tissue distribution of messenger ribonucleic acid encoding the rat glucagon-like peptide-1 receptor. Endocrinology (1996) 137:2968-78. doi: 10.1210/endo.137.7.8770921

223. Dunphy JL, Taylor RG, Fuller PJ. Tissue distribution of rat glucagon receptor and GLP-1 receptor gene expression1. Mol Cell Endocrinol. (1998) 141:17986. doi: 10.1016/S0303-7207(98)00096-3

224. Flock G, Baggio LL, Longuet C, Drucker DJ. Incretin receptors for glucagonlike peptide 1 and glucose-dependent insulinotropic polypeptide are essential for the sustained metabolic actions of vildagliptin in mice. Diabetes (2007) 56:3006-13. doi: 10.2337/db07-0697

225. Tomas E, Stanojevic V, Habener J. GLP-1 (9-36) amide metabolite suppression of glucose production in isolated mouse hepatocytes. Horm Metab Res. (2010) 42:657-62. doi: 10.1055/s-0030-1253421

226. Jin T, Weng J. Hepatic functions of GLP-1 and its based drugs: current disputes and perspectives. Am J Physiol Endocrinol Metab. (2016) 311:E6207. doi: 10.1152/ajpendo.00069.2016

227. Khound R, Su Q. GLP-1 mediates the intrinsic gut-liver metabolic signaling in anti-VLDL overproduction and insulin resistance in vagotomized mice. FASEB J. (2017) 31:137.1.

228. Chen H, Simar D, Pegg K, Saad S, Palmer C, Morris MJ. Exendin-4 is effective against metabolic disorders induced by intrauterine and postnatal overnutrition in rodents. Diabetologia (2014) 57:614-22. doi: 10.1007/s00125-013-3132-5

229. Wang X-C, Gusdon AM, Liu H, Qu S. Effects of glucagon-like peptide1 receptor agonists on non-alcoholic fatty liver disease and inflammation. World J Gastroenterol. (2014) 20:14821-30. doi: 10.3748/wjg.v20.i40.14821

230. Petit J-M, Cercueil J-P, Loffroy R, Denimal D, Bouillet B, Fourmont C, et al. Effect of liraglutide therapy on liver fat content in patients with inadequately controlled type 2 diabetes: the Lira-NAFLD study. J Clin Endocrinol Metab. (2016) 102:407-15. doi: 10.1210/jc.2016-2775

231. Yang M, Wang J, Wu S, Yuan L, Zhao X, Liu C, et al. Duodenal GLP-1 signaling regulates hepatic glucose production through a $\mathrm{PKC}-\delta$-dependent neurocircuitry. Cell Death Dis. (2017) 8:e2609. doi: 10.1038/cddis.2017.28

232. Ding X, Saxena NK, Lin S, Gupta N, Anania FA. Exendin-4, a glucagon-like protein-1 (GLP-1) receptor agonist, reverses hepatic steatosis in ob/ob mice. Hepatology (2006) 43:173-81. doi: 10.1002/hep.21006

233. Wang Y, Parlevliet E, Geerling J, Tuin S, Zhang H, Bieghs V, et al. Exendin-4 decreases liver inflammation and atherosclerosis development simultaneously by reducing macrophage infiltration. Br J Pharmacol. (2014) 171:723-34. doi: 10.1111/bph.12490

234. Xiao C, Bandsma RH, Dash S, Szeto L, Lewis GF. Exenatide, a glucagon-like peptide-1 receptor agonist, acutely inhibits intestinal lipoprotein production in healthy humans. Arterioscler Thromb Vasc Biol. (2012) 32:1513-9. doi: 10.1161/ATVBAHA.112.246207

235. He Q, Sha S, Sun L, Zhang J, Dong M. GLP-1 analogue improves hepatic lipid accumulation by inducing autophagy via AMPK/mTOR pathway. Biochem Biophys Res Commun. (2016) 476:196-203. doi: 10.1016/j.bbrc.2016.05.086

236. Sharma S, Mells JE, Fu PP, Saxena NK, Anania FA. GLP-1 analogs reduce hepatocyte steatosis and improve survival by enhancing the unfolded protein response and promoting macroautophagy. PLoS ONE (2011) 6:e25269. doi: 10.1371/journal.pone.0025269

237. Wang C, Li Q, Wang W, Guo L, Guo C, Sun Y, et al. GLP-1 contributes to increases in PGC-1alpha expression by downregulating miR23a to reduce apoptosis. Biochem Biophys Res Commun. (2015) 466:33-9. doi: 10.1016/j.bbrc.2015.08.092

238. Russell AP, Wada S, Vergani L, Hock MB, Lamon S, Léger B, et al. Disruption of skeletal muscle mitochondrial network genes and miRNAs in amyotrophic lateral sclerosis. Neurobiol Dis. (2013) 49:107-17. doi: 10.1016/j.nbd.2012.08.015

239. Lin J, Handschin C, Spiegelman BM. Metabolic control through the PGC-1 family of transcription coactivators. Cell Metab. (2005) 1:361-70. doi: 10.1016/j.cmet.2005.05.004

240. Baggio LL, Drucker DJ. Glucagon-like peptide-1 receptors in the brain: controlling food intake and body weight. J Clin Invest. (2014) 124:4223-6. doi: 10.1172/JCI78371

241. Cork SC, Richards JE, Holt MK, Gribble FM, Reimann F, Trapp S. Distribution and characterisation of Glucagon-like peptide-1 receptor expressing cells in the mouse brain. Mol Metab. (2015) 4:718-31. doi: 10.1016/j.molmet.2015.07.008

242. Bae CS, Song J. The role of glucagon-like peptide 1 (GLP1) in type 3 diabetes: GLP-1 controls insulin resistance, neuroinflammation and neurogenesis in the brain. Int J Mol Sci. (2017) 18:2493. doi: 10.3390/ijms18112493

243. Holscher C. The role of GLP-1 in neuronal activity and neurodegeneration. Vitam Horm. (2010) 84:331-54. doi: 10.1016/B978-0-12-381517-0.00013-8

244. Hamilton A, Patterson S, Porter D, Gault VA, Holscher C. Novel GLP1 mimetics developed to treat type 2 diabetes promote progenitor cell proliferation in the brain. J Neurosci Res. (2011) 89:481-9. doi: 10.1002/jnr.22565

245. Hunter K, Hölscher C. Drugs developed to treat diabetes, liraglutide and lixisenatide, cross the blood brain barrier and enhance neurogenesis. BMC Neurosci. (2012) 13:33. doi: 10.1186/1471-2202-13-33

246. Ten Kulve JS, van Bloemendaal L, Balesar R, IJzerman RG, Swaab DF, Diamant M, et al. Decreased hypothalamic glucagon-like peptide-1 receptor expression in type 2 diabetes patients. J Clin Endocrinol Metab. (2016) 101:2122-9. doi: 10.1210/jc.2015-3291

247. Abbas T, Faivre E, Holscher C. Impairment of synaptic plasticity and memory formation in GLP-1 receptor KO mice: interaction between type 2 diabetes and Alzheimer's disease. Behav Brain Res. (2009) 205:265-71. doi: 10.1016/j.bbr.2009.06.035

248. Heppner KM, Kirigiti M, Secher A, Paulsen SJ, Buckingham R, Pyke C, et al. Expression and distribution of glucagon-like peptide-1 receptor mRNA, protein and binding in the male nonhuman primate (Macaca mulatta) brain. Endocrinology (2015) 156:255-67. doi: 10.1210/en.2014-1675

249. Llewellyn-Smith IJ, Reimann F, Gribble FM, Trapp S. Preproglucagon neurons project widely to autonomic control areas in the mouse brain. Neuroscience (2011) 180:111-21. doi: 10.1016/j.neuroscience.2011.02.023

250. Cabou C, Burcelin R. GLP-1, the gut-brain, and brain-periphery axes. Rev Diabet Stud. (2011) 8:418-31. doi: 10.1900/RDS.2011.8.418

251. Tang-Christensen M, Larsen P, Goke R, Fink-Jensen A, Jessop D, Moller M, et al. Central administration of GLP-1-(7-36) amide inhibits food and water intake in rats. Am J Physiol Regulat Integr Comp Physiol. (1996) 271:R848-56. doi: 10.1152/ajpregu.1996.271.4.R848

252. Turton M, O'shea D, Gunn I, Beak S, Edwards C, Meeran K, et al. A role for glucagon-like peptide-1 in the central regulation of feeding. Nature (1996) 379:69. doi: 10.1038/379069a0

253. Meeran K, O'shea D, Edwards CMB, Turton MD, Heath MM, Gunn I, et al. Repeated intracerebroventricular administration of glucagon-like peptide-1(7-36) amide or exendin-(9-39) alters body weight in the rat. Endocrinology (1999) 140:244-50. doi: 10.1210/endo.140.1.6421 
254. Seo S, Ju S, Chung H, Lee D, Park S. Acute effects of glucagon-like peptide1 on hypothalamic neuropeptide and AMP activated kinase expression in fasted rats. Endocr J. (2008) 55:867-74. doi: 10.1507/endocrj.K08E-091

255. McMahon LR, Wellman PJ. PVN infusion of GLP-1-(7-36) amide suppresses feeding but does not induce aversion or alter locomotion in rats. Am J Physiol. (1998) 274:R23-9.

256. Sandoval DA, Bagnol D, Woods SC, D'alessio DA, Seeley RJ. Arcuate glucagon-like peptide 1 receptors regulate glucose homeostasis but not food intake. Diabetes (2008) 57:2046-54. doi: 10.2337/db07-1824

257. Lopez M, Dieguez C. Nogueiras R. Hypothalamic GLP-1: the control of BAT thermogenesis and browning of white fat. Adipocyte (2015) 4:141-5. doi: $10.4161 / 21623945.2014 .983752$

258. Gao Q, Horvath TL. Neuronal control of energy homeostasis. FEBS Lett. (2008) 582:132-41. doi: 10.1016/j.febslet.2007.11.063

259. Secher A, Jelsing J, Baquero AF, Hecksher-Sorensen J, Cowley MA, Dalboge LS, et al. The arcuate nucleus mediates GLP-1 receptor agonist liraglutide-dependent weight loss. J Clin Invest. (2014) 124:4473-88. doi: 10.1172/JCI75276

260. Sisley S, Gutierrez-Aguilar R, Scott M, D’Alessio DA, Sandoval DA, Seeley RJ. Neuronal GLP1R mediates liraglutide's anorectic but not glucose-lowering effect. J Clin Invest. (2014) 124:2456-63. doi: 10.1172/JCI72434

261. Reiner DJ, Mietlicki-Baase EG, McGrath LE, Zimmer DJ, Bence KK, Sousa GL, et al. Astrocytes regulate GLP-1 receptormediated effects on energy balance. J Neurosci. (2016) 36:3531-40. doi: 10.1523/JNEUROSCI.3579-15.2016

262. Shiraishi D, Fujiwara Y, Komohara Y, Mizuta H, Takeya M. Glucagonlike peptide-1 (GLP-1) induces M2 polarization of human macrophages via STAT3 activation. Biochem Biophys Res Commun. (2012) 425:304-8. doi: 10.1016/j.bbrc.2012.07.086

263. Anderberg RH, Richard JE, Eerola K, Lopez-Ferreras L, Banke E, Hansson C, et al. Glucagon-like peptide 1 and its analogs act in the dorsal raphe and modulate central serotonin to reduce appetite and body weight. Diabetes (2017) 66:1062-73. doi: 10.2337/db16-0755

264. De Silva A, Salem V, Long CJ, Makwana A, Newbould RD, Rabiner EA, et al. The gut hormones PYY 3-36 and GLP-1 7-36 amide reduce food intake and modulate brain activity in appetite centers in humans. Cell Metab. (2011) 14:700-6. doi: 10.1016/j.cmet.2011.09.010

265. Farr OM, Sofopoulos M, Tsoukas MA, Dincer F, Thakkar B, Sahin-Efe A, et al. GLP-1 receptors exist in the parietal cortex, hypothalamus and medulla of human brains and the GLP-1 analogue liraglutide alters brain activity related to highly desirable food cues in individuals with diabetes: a crossover, randomised, placebo-controlled trial. Diabetologia (2016) 59:95465. doi: 10.1007/s00125-016-3874-y

266. van Bloemendaal L, IJzerman RG, Ten Kulve JS, Barkhof F, Konrad RJ, Drent ML, et al. GLP-1 receptor activation modulates appetite- and reward-related brain areas in humans. Diabetes (2014) 63:4186-96. doi: 10.2337/db14-0849

267. Athauda D, Maclagan K, Skene SS, Bajwa-Joseph M, Letchford D, Chowdhury K, et al. Exenatide once weekly versus placebo in Parkinson's disease: a randomised, double-blind, placebo-controlled trial. Lancet (2017) 390:1664-75. doi: 10.1016/S0140-6736(17)31585-4

268. Farooq RK, Isingrini E, Tanti A, Le Guisquet AM, Arlicot N, Minier F, et al. Is unpredictable chronic mild stress (UCMS) a reliable model to study depression-induced neuroinflammation? Behav Brain Res. (2012) 231:130-7. doi: 10.1016/j.bbr.2012.03.020

269. Kitagishi Y, Kobayashi M, Kikuta K, Matsuda S. Roles of $\mathrm{PI} 3 \mathrm{~K} / \mathrm{AKT} / \mathrm{GSK} 3 / \mathrm{mTOR}$ pathway in cell signaling of mental illnesses. Depress Res Treat. (2012). 2012:752563. doi: 10.1155/2012/752563

270. Kim JY, Duan X, Liu CY, Jang MH, Guo JU, Pow-anpongkul N, et al. DISC1 regulates new neuron development in the adult brain via modulation of AKT-mTOR signaling through KIAA1212. Neuron (2009) 63:761-73. doi: 10.1016/j.neuron.2009.08.008

271. Li Y, Perry T, Kindy MS, Harvey BK, Tweedie D, Holloway HW, et al. GLP-1 receptor stimulation preserves primary cortical and dopaminergic neurons in cellular and rodent models of stroke and Parkinsonism. Proc Natl Acad Sci USA. (2009) 106:1285-90. doi: 10.1073/pnas.0806720106

272. Anderberg RH, Richard JE, Hansson C, Nissbrandt H, Bergquist F, Skibicka KP. GLP-1 is both anxiogenic and antidepressant; divergent effects of acute and chronic GLP-1 on emotionality. Psychoneuroendocrinology (2016) 65:54-66. doi: 10.1016/j.psyneuen.2015.11.021

273. Krass M, Volke A, Runkorg K, Wegener G, Lund S, Abildgaard A, et al. GLP-1 receptor agonists have a sustained stimulatory effect on corticosterone release after chronic treatment. Acta Neuropsychiatr. (2015) 27:25-32. doi: 10.1017/neu.2014.36

274. McIntyre RS, Powell AM, Kaidanovich-Beilin O, Soczynska JK, Alsuwaidan M, Woldeyohannes HO, et al. The neuroprotective effects of GLP-1: Possible treatments for cognitive deficits in individuals with mood disorders. Behav Brain Res. (2013) 237:164-71. doi: 10.1016/j.bbr.2012.09.021

275. Gejl M, Gjedde A, Egefjord L, Moller A, Hansen SB, Vang K, et al. In Alzheimer's disease, 6-month treatment with GLP-1 analog prevents decline of brain glucose metabolism: randomized, placebocontrolled, double-blind clinical trial. Front Aging Neurosci. (2016) 8:108. doi: 10.3389/fnagi.2016.00108

276. Svenningsson P, Wirdefeldt K, Yin L, Fang F, Markaki I, Efendic S, et al. Reduced incidence of Parkinson's disease after dipeptidyl peptidase4 inhibitors-A nationwide case-control study. Movement Disord. (2016) 31:1422-3. doi: 10.1002/mds. 26734

277. Aviles-Olmos I, Dickson J, Kefalopoulou Z, Djamshidian A, Kahan J, Ell $\mathrm{P}$, et al. Motor and cognitive advantages persist 12 months after exenatide exposure in Parkinson's disease. J Parkinsons Dis. (2014) 4:337-44. doi: 10.3233/JPD-140364

278. Aviles-Olmos I, Dickson J, Kefalopoulou Z, Djamshidian A, Ell P, Soderlund T, et al. Exenatide and the treatment of patients with Parkinson's disease. $J$ Clin Investig. (2013) 123:2730-36. doi: 10.1172/JCI68295

279. Hölscher C. Potential role of glucagon-like peptide-1 (GLP-1) in neuroprotection. CNS Drugs (2012) 26:871-82. doi: 10.2165/11635890-000000000-00000

280. Ziabreva I, Perry E, Perry R, Minger SL, Ekonomou A, Przyborski S, et al. Altered neurogenesis in Alzheimer's disease. J Psychosom Res. (2006) 61:31116. doi: 10.1016/j.jpsychores.2006.07.017

281. Holmes C, Cunningham C, Zotova E, Culliford D, Perry V. Proinflammatory cytokines, sickness behavior, and Alzheimer disease. Neurology (2011) 77:212-8. doi: 10.1212/WNL.0b013e318225ae07

282. Chen SY, Chen TF, Lai LC, Chen JH, Sun Y, Wen LL, et al. Sequence variants of interleukin 6 (IL-6) are significantly associated with a decreased risk of late-onset alzheimer's disease. J Neuroinflammation (2012) 9:21. doi: 10.1186/1742-2094-9-21

283. Serrano-Pozo A, Frosch MP, Masliah E, Hyman BT. Neuropathological Alterations in Alzheimer Disease. Cold Spring Harbor Perspect Med. (2011) 1:a006189. doi: 10.1101/cshperspect.a006189

284. Dickson DW. Parkinson's Disease and Parkinsonism: neuropathology. Cold Spring Harbor Perspect Med. (2012) 2:a009258. doi: 10.1101/cshperspect.a009258

285. Perlson E, Maday S, Fu MM, Moughamian AJ, Holzbaur EL. Retrograde axonal transport: pathways to cell death? Trends Neurosci. (2010) 33:335-44. doi: 10.1016/j.tins.2010.03.006

286. Hölscher C. Central effects of GLP-1: new opportunities for treatments of neurodegenerative diseases. J Endocrinol. (2014) 221:T31-41. doi: 10.1530/JOE-13-0221

287. Harkavyi A, Whitton PS. Glucagon-like peptide 1 receptor stimulation as a means of neuroprotection. Brit J Pharmacol. (2010) 159:495-501. doi: 10.1111/j.1476-5381.2009.00486.x

288. Panagaki T, Michael M, Hölscher C. Liraglutide restores chronic ER stress, autophagy impairments and apoptotic signalling in SH-SY5Y cells. Sci Rep. (2017) 7:16158. doi: 10.1038/s41598-017-16488-x

289. Chen J, Wang Z, Mao Y, Zheng Z, Chen Y, Khor S, et al. Liraglutide activates autophagy via GLP-1R to improve functional recovery after spinal cord injury. Oncotarget (2017) 8:85949-68. doi: 10.18632/oncotarget.20791

290. Iwai T, Ito S, Tanimitsu K, Udagawa S, Oka J. Glucagon-like peptide-1 inhibits LPS-induced IL-1beta production in cultured rat astrocytes. Neurosci Res. (2006) 55:352-60. doi: 10.1016/j.neures.2006.04.008

291. Solmaz V, Cinar BP, Yigitturk G, Cavusoglu T, Taskiran D, Erbas O. Exenatide reduces TNF-alpha expression and improves hippocampal neuron numbers and memory in streptozotocin treated rats. Eur J Pharmacol. (2015) 765:4827. doi: 10.1016/j.ejphar.2015.09.024 
292. Parthsarathy V, Holscher C. The type 2 diabetes drug liraglutide reduces chronic inflammation induced by irradiation in the mouse brain. Eur $J$ Pharmacol. (2013) 700:42-50. doi: 10.1016/j.ejphar.2012.12.012

293. Holscher C. The incretin hormones glucagonlike peptide 1 and glucosedependent insulinotropic polypeptide are neuroprotective in mouse models of Alzheimer's disease. Alzheimers Dement. (2014) 10:S47-54. doi: 10.1016/j.jalz.2013.12.009

294. Fan Z, Aman Y, Ahmed I, Chetelat G, Landeau B, Chaudhuri KR, et al. Influence of microglial activation on neuronal function in Alzheimer's and Parkinson's disease dementia. Alzheimers Dement J Alzheimers Assoc. (2015) 11:608-621.e7. doi: 10.1016/j.jalz.2014.06.016

295. Ouchi Y, Yoshikawa E, Sekine Y, Futatsubashi M, Kanno T, Ogusu T, et al. Microglial activation and dopamine terminal loss in early Parkinson's disease. Ann Neurol. (2005) 57:168-75. doi: 10.1002/ana.20338

296. Mills CD, Kincaid K, Alt JM, Heilman MJ, Hill AM. M-1/M-2 macrophages and the Th1/Th2 paradigm. J Immunol. 164 (2000) 6166-73. doi: 10.4049/jimmunol.164.12.6166

297. Martinez FO, Gordon S. The M1 and M2 paradigm of macrophage activation: time for reassessment. F1000Prime Rep. (2014) 6:13. doi: 10.12703/P6-13

298. Harkavyi A, Abuirmeileh A, Lever R, Kingsbury AE, Biggs CS, Whitton PS. Glucagon-like peptide 1 receptor stimulation reverses key deficits in distinct rodent models of Parkinson's disease. J Neuroinflammation (2008) 5:19. doi: 10.1186/1742-2094-5-19

299. Zhang F, Shi JS, Zhou H, Wilson BC, Hong JS, Gao HM. Resveratrol protects dopamine neurons against lipopolysaccharide-induced neurotoxicity through its anti-inflammatory actions. Mol Pharmacol. (2010) 78:466-77. doi: $10.1124 / \mathrm{mol} .110 .064535$

300. Ghosh A, Roy A, Liu X, Kordower JH, Mufson EJ, Hartley DM, et al. Selective inhibition of NF- $\mathrm{KB}$ activation prevents dopaminergic neuronal loss in a mouse model of Parkinson's disease. Proc Natl Acad Sci USA. (2007) 104:18754-59. doi: 10.1073/pnas.0704908104

301. Khasnavis S, Jana A, Roy A, Mazumder M, Bhushan B, Wood T, et al. Suppression of nuclear factor- $\mathrm{\kappa B}$ activation and inflammation in microglia by physically modified saline. J Biol Chem. (2012) 287:29529-42. doi: 10.1074/jbc.M111.338012

302. Perry T, Lahiri DK, Sambamurti K, Chen D, Mattson MP, Egan JM, et al. Glucagon-like peptide-1 decreases endogenous amyloid- $\beta$ peptide $(A \beta)$ levels and protects hippocampal neurons from death induced by $A \beta$ and iron. J Neurosci Res. (2003) 72:603-12. doi: 10.1002/jnr.10611

303. Qin Z, Sun Z, Huang J, Hu Y, Wu Z, Mei B. Mutated recombinant human glucagon-like peptide-1 protects SH-SY5Y cells from apoptosis induced by amyloid- $\beta$ peptide (1-42). Neurosci Lett. (2008) 444:217-21. doi: 10.1016/j.neulet.2008.08.047

304. Li H, Lee CH, Yoo KY, Choi JH, Park OK, Yan BC, et al. Chronic treatment of exendin-4 affects cell proliferation and neuroblast differentiation in the adult mouse hippocampal dentate gyrus. Neurosci Lett. (2010) 486:38-42. doi: $10.1016 /$ j.neulet.2010.09.040

305. Xu W, Yang Y, Yuan G, Zhu W, Ma D, Hu S. Exendin-4, a glucagonlike peptide-1 receptor agonist, reduces Alzheimer disease-associated tau hyperphosphorylation in the hippocampus of rats with type 2 diabetes. $J$ Investig Med. (2015) 63:267-72. doi: 10.1097/JIM.0000000000000129

306. Duka T, Duka V, Joyce JN, Sidhu A. $\alpha$-Synuclein contributes to GSK$3 \beta$-catalyzed Tau phosphorylation in Parkinson's disease models. FASEB J. (2009) 23:2820-30. doi: 10.1096/fj.08-120410

307. Hur EM, Zhou FQ. GSK3 signalling in neural development. Nat Rev Neurosci. (2010) 11:539. doi: 10.1038/nrn2870

308. Medina M, Avila J. New insights into the role of glycogen synthase kinase-3 in Alzheimer's disease. Expert Opin Ther Targets (2014) 18:69-77. doi: 10.1517/14728222.2013.843670

309. Golpich M, Amini E, Hemmati F, Ibrahim NM, Rahmani B, Mohamed $\mathrm{Z}$, et al. Glycogen synthase kinase-3 beta (GSK-3 $\beta$ ) signaling: implications for Parkinson's disease. Pharmacol Res. (2015) 97:16-26. doi: 10.1016/j.phrs.2015.03.010

310. Chen S, An FM, Yin L, Liu AR, Yin DK, Yao WB, Gao XD. Glucagonlike peptide-1 protects hippocampal neurons against advanced glycation end product-induced tau hyperphosphorylation. Neuroscience (2014) 256:13746. doi: 10.1016/j.neuroscience.2013.10.038
311. Ma DL, Chen FQ, Xu WJ, Yue WZ, Yuan G, Yang Y. Early intervention with glucagon-like peptide 1 analog liraglutide prevents tau hyperphosphorylation in diabetic $\mathrm{db} / \mathrm{db}$ mice. J Neurochem. (2015) 135:301-8. doi: 10.1111/jnc.13248

312. Yuan YH, Yan WF, Sun JD, Huang JY, Mu Z, Chen NH. The molecular mechanism of rotenone-induced $\alpha$-synuclein aggregation: emphasizing the role of the calcium/GSK3 $\beta$ pathway. Toxicol Lett. (2015) 233:163-71. doi: 10.1016/j.toxlet.2014.11.029

313. Nath S, Goodwin J, Engelborghs Y, Pountney D. Raised calcium promotes $\alpha$-synuclein aggregate formation. Mol Cell Neurosci. (2011) 46:516-26. doi: 10.1016/j.mcn.2010.12.004

314. Swarnkar S, Goswami P, Kamat PK, Gupta S, Patro IK, Singh S, et al. Rotenone-induced apoptosis and role of calcium: a study on Neuro-2a cells. Arch Toxicol. (2012) 86:1387-97. doi: 10.1007/s00204-012-0853-Z

315. Han WN, Hölscher C, Yuan L, Yang W, Wang XH, Wu MN, et al. Liraglutide protects against amyloid- $\beta$ protein-induced impairment of spatial learning and memory in rats. Neurobiol Aging (2013) 34:576-88. doi: 10.1016/j.neurobiolaging.2012.04.009

316. Deheshi S, Dabiri B, Fan S, Tsang M, Rintoul GL. Changes in mitochondrial morphology induced by calcium or rotenone in primary astrocytes occur predominantly through ros-mediated remodeling. J Neurochem. (2015) 133:684-99. doi: 10.1111/jnc. 13090

317. Wyatt CN, Buckler KJ. The effect of mitochondrial inhibitors on membrane currents in isolated neonatal rat carotid body type I cells. J Physiol. (2004) 556:175-91. doi: 10.1113/jphysiol.2003.058131

318. Pfleger J, He M, Abdellatif M. Mitochondrial complex II is a source of the reserve respiratory capacity that is regulated by metabolic sensors and promotes cell survival. Cell Death Dis. (2015) 6:e1835. doi: $10.1038 /$ cddis. 2015.202

319. Martin Brand D, David Nicholls G. Assessing mitochondrial dysfunction in cells. Biochem J. (2011) 435:297-312. doi: 10.1042/BJ20110162

320. Gilman CP, Perry T, Furukawa K, Grieg NH, Egan JM, Mattson MP. Glucagon-like peptide 1 modulates calcium responses to glutamate and membrane depolarization in hippocampal neurons. J Neurochem. (2003) 87:1137-44. doi: 10.1046/j.1471-4159.2003.02073.x

321. Sharma MK, Jalewa J, Holscher C. Neuroprotective and anti-apoptotic effects of liraglutide on SH-SY5Y cells exposed to methylglyoxal stress. J Neurochem. (2014) 128:459-71. doi: 10.1111/jnc.12469

322. Li L, Hölscher C. Common pathological processes in Alzheimer disease and type 2 diabetes: a review. Brain Res Rev. (2007) 56:384-402. doi: 10.1016/j.brainresrev.2007.09.001

323. Stockhorst U, de Fries D, Steingrueber HJ, Scherbaum WA. Insulin and the CNS: effects on food intake, memory, and endocrine parameters and the role of intranasal insulin administration in humans. Physiol Behav. (2004) 83:47-54. doi: 10.1016/S0031-9384(04)00348-8

324. Hoyer S. Glucose metabolism and insulin receptor signal transduction in Alzheimer disease. Eur $J$ Pharmacol. (2004) 490:115-25. doi: 10.1016/j.ejphar.2004.02.049

325. Calsolaro V, Edison P. Novel GLP-1 (Glucagon-Like Peptide-1) analogues and insulin in the treatment for Alzheimer's disease and other neurodegenerative diseases. CNS Drugs (2015) 29:1023-39. doi: $10.1007 / \mathrm{s} 40263-015-0301-8$

326. Candeias E, Sebastião I, Cardoso S, Carvalho C, Santos MS, Oliveira CR, et al. Brain GLP-1/IGF-1 Signaling and autophagy mediate exendin-4 protection against apoptosis in type 2 diabetic rats. Mol Neurobiol. (2017) 55:4030-50. doi: 10.1007/s12035-017-0622-3

327. McClean PL, Gault VA, Harriott P, Hölscher C. Glucagon-like peptide1 analogues enhance synaptic plasticity in the brain: a link between diabetes and Alzheimer's disease. Eur J Pharmacol. (2010) 630:158-62. doi: 10.1016/j.ejphar.2009.12.023

328. Gault VA, Hölscher C. GLP-1 agonists facilitate hippocampal LTP and reverse the impairment of LTP induced by beta-amyloid. Eur J Pharmacol. (2008) 587:112-7. doi: 10.1016/j.ejphar.2008.03.025

329. Wang X, Li L, Hölscher C, Pan Y, Chen X, Qi J. Val8-glucagonlike peptide-1 protects against $\mathrm{A} \beta 1-40$-ind uced impairment of hippocampal late-phase long-term potentiation and spatial learning in rats. Neuroscience (2010) 170:1239-48. doi: 10.1016/j.neuroscience.2010. 08.028 
330. Gengler S, McClean PL, McCurtin R, Gault VA, Hölscher C. Val (8) GLP-1 rescues synaptic plasticity and reduces dense core plaques in APP/PS1 mice. Neurobiol Aging (2012) 33:265-76. doi: 10.1016/j.neurobiolaging.2010.02.014

331. Hirsch EC, Jenner P. Przedborski S, Pathogenesis of Parkinson's disease. Mov Disord. (2013) 28:24-30. doi: 10.1002/mds.25032

332. Schapira AH. Mitochondria in the aetiology and pathogenesis of Parkinson's disease. Lancet Neurol. (2008) 7:97-109. doi: 10.1016/S1474-4422(07)70327-7

333. Yang JL, Chen WY, Chen YP, Kuo CY, Chen SD. Activation of GLP-1 receptor enhances neuronal base excision repair via PI3K-AKT-induced expression of apurinic/apyrimidinic endonuclease 1. Theranostics (2016) 6:2015-27. doi: 10.7150/thno.15993

334. Lennox R, Porter DW, Flatt PR, Holscher C, Irwin N, Gault VA. Comparison of the independent and combined effects of sub-chronic therapy with metformin and a stable GLP-1 receptor agonist on cognitive function, hippocampal synaptic plasticity and metabolic control in high-fat fed mice. Neuropharmacology (2014) 86:22-30. doi: 10.1016/j.neuropharm.2014.06.026
335. Donmez G, Outeiro TF. SIRT1 and SIRT2: emerging targets in neurodegeneration. EMBO Mol Med. (2013) 5:344-52. doi: 10.1002/emmm.201302451

336. Donmez G, Arun A, Chung CY, McLean PJ, Lindquist S, Guarente L. SIRT1 protects against $\alpha$-synuclein aggregation by activating molecular chaperones. J Neurosci. (2012) 32:124-32. doi: 10.1523/JNEUROSCI.344211.2012

Conflict of Interest Statement: The authors declare that the research was conducted in the absence of any commercial or financial relationships that could be construed as a potential conflict of interest.

Copyright (C) 2018 Rowlands, Heng, Newsholme and Carlessi. This is an open-access article distributed under the terms of the Creative Commons Attribution License (CC $B Y)$. The use, distribution or reproduction in other forums is permitted, provided the original author(s) and the copyright owner(s) are credited and that the original publication in this journal is cited, in accordance with accepted academic practice. No use, distribution or reproduction is permitted which does not comply with these terms. 